\title{
Geochemistry, Nd isotopes and U-Pb geochronology of a 2350 Ma TTG suite, Minas Gerais, Brazil: Implications for the crustal evolution of the southern São Francisco craton
}

\author{
Luís Antônio Rosa Seixas ${ }^{\mathrm{a}, *}$, Jean David ${ }^{\mathrm{b}}$, Ross Stevenson ${ }^{\mathrm{b}}$ \\ a Departamento de Geologia, Universidade Federal de Ouro Preto, Morro do Cruzeiro, CEP 35400-000, Ouro Preto, Brazil \\ b GEOTOP Université du Québec à Montréal, P.O. Box 8888, Station Centre Ville, Montréal, Québec H3C 3P8, Canada
}

\section{A R T I C L E I N F O}

\section{Article history:}

Received 24 June 2011

Received in revised form

11 November 2011

Accepted 11 November 2011

Available online 22 November 2011

\section{Keywords:}

TTG

Nd isotopes

$\mathrm{U}-\mathrm{Pb}$ geochronology

Geochemistry

$2350 \mathrm{Ma}$

São Francisco craton

\begin{abstract}
A B S T R A C T
The Paleoproterozoic is considered the main period of crustal growth in the South American continent with voluminous production of granitoid suites emplaced during the onset of the ca. 2.2-2.1 Ga TransAmazonian orogeny. This work documents and interprets mineral chemistry, whole rock geochemistry, $\mathrm{Nd}$ isotopes and $\mathrm{U}-\mathrm{Pb}$ geochronology data for the high-aluminium Lagoa Dourada TTG suite. This suite constitutes a hitherto unknown episode of Paleoproterozoic (ca. $2350 \mathrm{Ma}$ ) juvenile felsic plutonism in the southern São Francisco craton, Minas Gerais, Brazil. It is also a rare example of juvenile continental crust production in the global crustal age-gap between 2.45 and $2.2 \mathrm{Ga}$. The suite is composed of metaluminous to slightly peraluminous, low-Mg\#, low-K and high-Ca, biotite-hornblende to hornblende-biotite ( \pm garnet-magnetite) tonalites and biotite trondhjemites, varying from $\sim 62$ to $73 \mathrm{wt} . \% \mathrm{SiO}_{2}$. The trace element geochemistry of the suite is characterized by mildly depleted Nd isotope compositions $\left[\varepsilon_{\mathrm{Nd}}(t)=+1.0\right.$ to +2.1 ], low large-ion-lithophile element (LILE, i.e., Rb, Ba, and including the highly incompatible Th) and heavy Rare Earth element ( $\mathrm{REE}, \mathrm{Yb}<1.00 \mathrm{ppm}$ ) contents. The suite is also characterized by high $\mathrm{Sr} / \mathrm{Y}$ ratios ( $\geq 41$ up to 81 ), high $(\mathrm{La} / \mathrm{Yb})_{\mathrm{N}}$ ratios ( $\geq 12$ up to 46 ), and positive Eu/Eu* anomalies. These data are consistent with the derivation of the suite from a tholeiitic metabasaltic source, which had a short crustal residence time prior to melting. The chemical diversity of the suite is attributed mainly to the fractional crystallization of hornblende and accessory minerals, coupled with plagioclase accumulation in the tonalitic parental melt. Emplacement of new batches of magma could explain samples which diverge from the proposed liquid line of descent of the suite. The composition and age of the Lagoa Dourada suite suggest a link with the accretion of greenstone belt packages in an intra-oceanic tectonic setting.
\end{abstract}

(c) 2011 Elsevier B.V. All rights reserved.

\section{Introduction}

High-aluminium tonalite-trondhjemite-granodioritic suites (TTG suites, Barker, 1979; Condie, 2005; Martin et al., 2005) are characterized by $\mathrm{Mg} \# \leq 50\left(\mathrm{Mg} \#=100 \times \mathrm{mol} \mathrm{MgO} /\left[\mathrm{MgO}^{2}+\mathrm{FeO}_{t}\right]\right)$, low $\mathrm{Cr}$ and $\mathrm{Ni}$ (average 29 and $14 \mathrm{ppm}$, respectively), high $\mathrm{Al}_{2} \mathrm{O}_{3}$ $\left(>15 \%\right.$ at $\left.70 \% \mathrm{SiO}_{2}\right)$, high $\mathrm{Sr}(>300 \mathrm{ppm})$ and strongly fractionated light/heavy REE patterns, with low heavy $\operatorname{REE~}(\mathrm{Yb}<1.8 \mathrm{ppm})$ and $\mathrm{Y}$ $(<20 \mathrm{ppm})$. A number of geochemical, petrologic and experimental studies have shown that these suites can be derived from partial melting of tholeiitic metabasaltic rocks, leaving garnet amphibolite to eclogite residues (Martin, 1986; Drummond and Defant, 1990; Rapp and Watson, 1995; Rapp, 1997; Willie et al., 1997; Clemens

\footnotetext{
* Corresponding author. Tel.: +55 313559 1600; fax: +55 3135591606

E-mail address: luseixas@degeo.ufop.br (L.A.R. Seixas).
}

et al., 2006). Tectonic settings suggested for these suites commonly include amphibolitic lower continental crust, mafic rocks at the base of thickened arc crust or at the roots of an oceanic plateau, or young descending slabs (Martin, 1986; Drummond et al., 1996; Petford and Atherton, 1996; Barnes et al., 1996; White et al., 1999; Whalen et al., 2002; Smithies et al., 2003). TTG suites with Nd isotope compositions in the range of depleted mantle values at the time of crystallization are attributed to be a consequence of the two step model for the generation of these rocks: extraction of basaltic precursors from the mantle, followed soon after by high pressure melting at garnet amphibolitic to eclogitic conditions, in order to preserve the isotopic composition of the mafic protolith (Martin, 1987; Barnes et al., 1996; Clemens et al., 2006; Stevenson et al., 2009).

The Paleoproterozoic is a particularly important period of crustal growth for the South American continent, with the production of numerous juvenile, subduction-zone related granitoid 


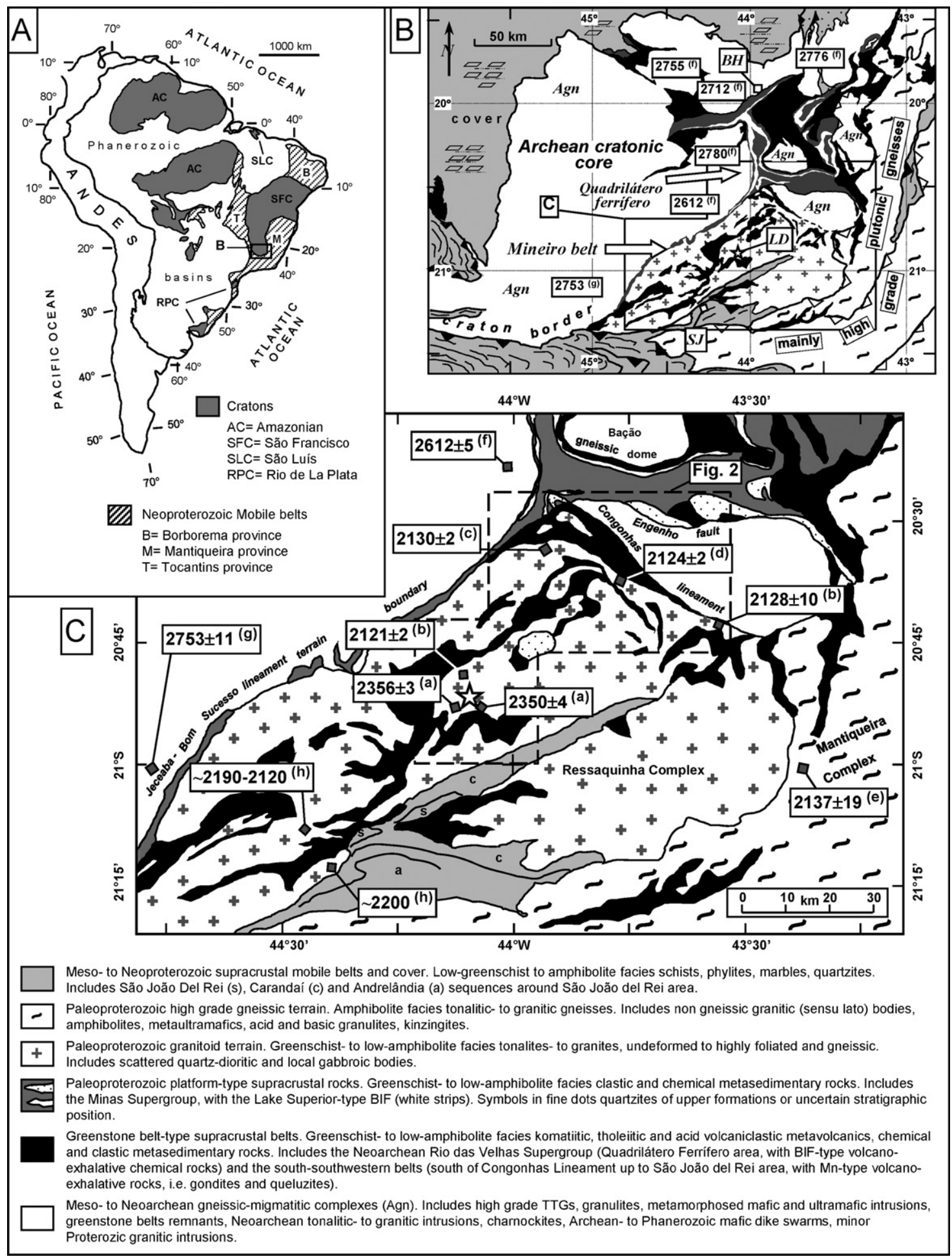

Fig. 1. The southern São Francisco craton (SFC) in relation to the major tectonic units of the South America continent (A). Boxes B and C show the location of the Lagoa Dourada suite (star) inside the Mineiro belt.

Adapted with modifications from Hartmann and Delgado (2001, A), Teixeira et al. (2000, B) and Heineck et al. (2003, B and C). The age of crystallization of selected granitoid suites (million years) are highlighted in the little boxes in B and C. Source of data: (a) this article; (b) unpublished, first author's data; (c) Noce (1995); (d) Noce et al. (2000); (e) Noce et al. (2007a); (f) Noce et al. (2007b); (g) Campos and Carneiro (2008); (h) Ávila et al. (2010, and references therein, range of ages from different plutons). Legend of cities in B: BH: Belo Horizonte, LD: Lagoa Dourada, SJ: São João Del Rei.

suites associated with the ca. 2.2-2.1 Ga Trans-Amazonian orogeny (Cordani and Sato, 1999; Almeida et al., 2000). This paper provides new mineralogical, whole rock geochemical, $\mathrm{U}-\mathrm{Pb}$ and Nd-isotope data for the Lagoa Dourada TTG suite. This ca. 2350 Ma suite represents a hitherto unknown earlier period of crustal growth in the Paleoproterozoic of southeastern Brazil and a rare example of juvenile crustal growth in an era with a paucity of global crust formation (Condie et al., 2009a,b; Condie and Aster, 2010). 


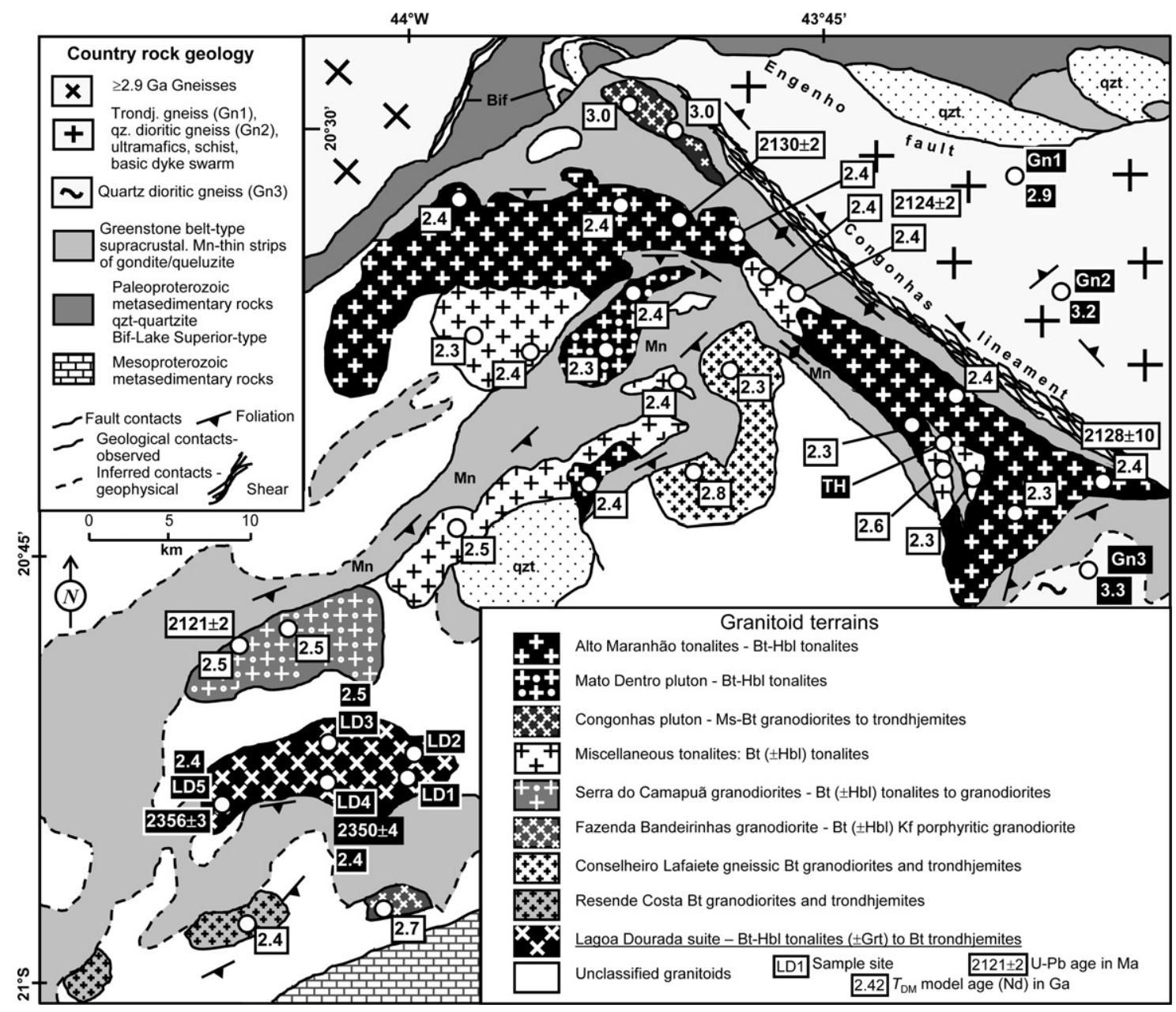

Fig. 2. Geological context of the Lagoa Dourada suite in relation to the surrounding granitoid terrains, southern Quadrilátero Ferrífero area. Classification of the granitoid suites according to first author's unpublished data (see summary in Table 1).

Source: Geology adapted from Heineck et al. (2003) with modifications.

\section{Geological setting}

The Lagoa Dourada suite outcrops within a Paleoproterozoic belt bordering the Archean nuclei of the southern São Francisco craton, on the southern edge of the Quadrilátero Ferrífero region, Minas Gerais, southeastern Brazil (Fig. 1). This region is known for its abundance of Late-Archean and Paleoproterozoic rock-packages and comprises one of the most important gold and iron provinces of the South American continent (Almeida et al., 2000; Hartmann and Delgado, 2001). The Archean rocks of the Quadrilátero Ferrífero area consist of the well-preserved ca. $2.77 \mathrm{Ga}$ Rio das Velhas greenstone belt, with greenschist to low-amphibolite facies volcano-sedimentary successions dominated by tholeiitic and komatiitic volcanic rocks and acid volcaniclastics, followed by volcano-exhalative banded iron formations and upper turbiditic, graywacke-sandstone and conglomerate-sandstone formations (Noce et al., 2005; Baltazar and Zuchetti, 2007). The greenstone belt is surrounded by $>2.9 \mathrm{Ga}$ high grade banded TTG gneisses and intrusive Neoarchean tonalitic to granitic plutonic suites (Machado et al., 1992; Machado and Carneiro, 1992; Teixeira et al., 1996; Noce et al., 2007b). The Archean rocks are covered by a thick platformal metasedimentary sequence-the Minas Supergroup, deposited between $\sim 2.5$ and 2.12 Ga (Dorr, 1969; Machado et al., 1996; Alkmim and Marshak, 1998; Hartmann et al., 2006). Extensive areas of intermediate to felsic plutonic rocks are exposed on the southern and eastern edge of the Quadrilátero Ferrífero and are collectively grouped into a single lithotectonic unit referred to as Mineiro belt (Fig. 1, Noce et al., 2000; Teixeira et al., 2000). The plutonic rocks of the Mineiro belt intrude elongated greenstone belts trending NE-SW from Congonhas lineament in the north, to São João Del Rei in the southwest (Fig. 1). These supracrustal sequences are composed mainly of tholeiitic and komatiitic metavolcanic rocks interleaved with metamorphosed volcano-exhalative manganese sedimentary rocks (Toledo, 2002; Ávila et al., 2010).

The Mineiro belt is broadly divided into a western and an eastern domain. The western domain (Fig. 1) consists of wide areas of massive to variably deformed tonalitic, trondhjemitic and granodioritic to granitic plutons (including the Lagoa Dourada suite), and minor scattered gabbroic and dioritic bodies, all of which are partially overlain by the low greenschist facies metasedimentary rocks of the Mesoproterozoic to Neoproterozoic São João Del Rei and Andrelândia Groups. The eastern domain of the Mineiro belt is characterized by a predominance of homogeneous to banded medium- to highgrade plutonic orthogneisses-labeled as Mantiqueira Complex in Fig. 1. The major period of the intermediate to felsic plutonism of the Mineiro belt is ascribed to be ca. 2.2-2.1 Ga in accordance with the Trans-Amazonian tectonic cycle of the South American Platform (Noce et al., 2000; Silva et al., 2002; Noce et al., 2007a; 
Table 1

Sumary of field and petrographic features for granitoids and associated country rocks from southern Quadrilátero Ferrífero region, Minas Gerais.

\begin{tabular}{|c|c|c|c|c|}
\hline Group & $\begin{array}{l}\text { Field aspects. Known areal } \\
\text { exposition (KAE) }\end{array}$ & $\begin{array}{l}\text { QAP classif. Ab-An-Or } \\
\text { classif. }\end{array}$ & $\%$ of mafic minerals & Accessory minerals \\
\hline Lagoa Dourada suite & $\begin{array}{l}\text { Foliated to gneissic, with variable } \\
\text { grain size and mafic mineral } \\
\text { contents. Intruded by multiple } \\
\text { crosscutting aplitic diking. } \\
\mathrm{KAE}>50 \mathrm{~km}^{2} \text {. }\end{array}$ & $\begin{array}{l}\text { To to Tdj } \\
\text { To }\end{array}$ & $\begin{array}{l}<10 \% \text { to } 25 \% \\
\text { Hbl absent to }>\mathrm{Bt}\end{array}$ & $\begin{array}{l}\text { Ap, Zrn, Ttn, Aln and } \pm G r t \text {, } \\
\text { with Mgt. Magnetic in } \\
\text { hand specimen }\end{array}$ \\
\hline Alto Maranhão tonalite & $\begin{array}{l}\text { Abundant magma mingling } \\
\text { structures with dioritic magmatic } \\
\text { enclaves. Generally well foliated } \\
\text { and with multiple syn- to } \\
\text { post-magmatic diking. KAE }>100 \text { to } \\
250 \mathrm{~km}^{2} \text {. }\end{array}$ & $\begin{array}{l}\text { Qz-Di to To } \\
\text { To/Gd ( } \pm \text { Tdj) }\end{array}$ & $\begin{array}{l}15-45 \% \\
\text { Hbl:Bt ratio } 0.8-1.3\end{array}$ & $\begin{array}{l}\text { Ap, Zrn, Aln, Ilm, Ttn. } \\
\text { Growth of Ep over Aln }\end{array}$ \\
\hline Mato Dentro pluton & $\begin{array}{l}\text { Abundant magma mingling } \\
\text { structures with dioritic magmatic } \\
\text { enclaves in the most mafic portions } \\
\text { of the pluton. KAE }>15 \text { to } 30 \mathrm{~km}^{2} \text {. }\end{array}$ & $\begin{array}{l}\text { To to Gd } \\
\text { To }\end{array}$ & $\begin{array}{l}<10 \% \text { to } 25 \% \\
\text { Hbl may be absent }\end{array}$ & $\begin{array}{l}\text { Same as Alto Maranhão } \\
\text { tonalite }\end{array}$ \\
\hline Congonhas pluton & $\begin{array}{l}\text { Massive to foliated or sheared, } \\
\text { with heterogeneous biotite } \\
\text { distribution, from randomly } \\
\text { scattered to clustered in biotite } \\
\text { rich centimeter scale micaceous } \\
\text { enclaves. KAE }<20 \mathrm{~km}^{2} \text {. }\end{array}$ & $\begin{array}{l}\text { Gd to Tdj } \\
\text { Tdj and boundary Tdj/Gt }\end{array}$ & $<10 \%$, with Bt and Ms & $\begin{array}{l}\text { Mainly Zrn and Ap. Biotite } \\
\text { rich enclaves with Ms, Ilm, } \\
\text { Ttn, Zrn, Ap, and rare Aln. }\end{array}$ \\
\hline Miscelaneous tonalites & $\begin{array}{l}\text { Scarce dioritic magmatic enclaves. } \\
\text { Well foliated, sometimes gneissic } \\
\text { in shear zones. Locally with } \\
\text { xenoliths and/or roof pendants of } \\
\text { amphibolite country rocks. } \\
\text { KAE }>50 \mathrm{~km}^{2} \text {. }\end{array}$ & $\begin{array}{l}\text { To/Tdj or Gd } \\
\text { To/Tdj }\end{array}$ & $\begin{array}{l}<10 \% \text { to } 20 \% \\
\text { Hbl absent or subortinate } \\
\text { to } \mathrm{Bt}\end{array}$ & $\begin{array}{l}\text { Same as Alto Maranhão } \\
\text { tonalite }\end{array}$ \\
\hline Serra do Camapuã tonalites & $\begin{array}{l}\text { Scarce dioritic magmatic enclaves, } \\
\text { with amphibolite wall rock } \\
\text { xenoliths. Slightly to well foliated. } \\
\text { KAE }>50 \mathrm{~km}^{2} \text {. }\end{array}$ & $\begin{array}{l}\text { To to Gd } \\
\text { To/Tdj/Gd boundary }\end{array}$ & $\begin{array}{l}<10 \% \text { to } 15 \% \\
\text { Hbl absent or very } \\
\text { subortinate to } \mathrm{Bt}\end{array}$ & $\begin{array}{l}\text { Same as Alto Maranhão } \\
\text { tonalite }\end{array}$ \\
\hline $\begin{array}{l}\text { Fazenda Bandeirinhas } \\
\text { granodiorite }\end{array}$ & $\begin{array}{l}\text { Kf-porphyritic Hbl-Bt granodiorite, } \\
\text { well foliated to gneissic, with } \\
\text { folded felsic leucocratic aplitic and } \\
\text { pegmatitic dikes. KAE not } \\
\text { determined. }\end{array}$ & $\begin{array}{l}\mathrm{Gd} \\
\mathrm{Gd}\end{array}$ & $\begin{array}{l}<10 \% \text { to } 20 \% \\
\text { Hbl absent or subortinate } \\
\text { to } \mathrm{Bt}\end{array}$ & $\begin{array}{l}\text { Same as previous, with Mgt } \\
\text { instead of Ilm. Magnetic in } \\
\text { hand specimen }\end{array}$ \\
\hline $\begin{array}{l}\text { Conselheiro Lafaiete } \\
\text { trondhjemites and } \\
\text { grano-diorites }\end{array}$ & $\begin{array}{l}\text { Foliated to gneissic, locally with } \\
\text { complex fold patterns and multiple } \\
\text { felsic trondhjemitic and granitic } \\
\text { dyking. KAE }>50 \mathrm{~km}^{2} \text {. }\end{array}$ & $\begin{array}{l}\text { Gd and Tdj } \\
\text { Gd/Tdj/Gt boundary }\end{array}$ & $\begin{array}{l}\leq 10 \% \text {, only Bt, partially } \\
\text { replaced by muscovite }\end{array}$ & $\begin{array}{l}\text { Ap, Zrn, Ttn, Aln. Growth of } \\
\text { Ep over Aln }\end{array}$ \\
\hline $\begin{array}{l}\text { Resende Costa granodio - } \\
\text { rites }\end{array}$ & $\begin{array}{l}\text { Homogeneous well foliated, with } \\
\text { deformed aplite and pegmatite } \\
\text { dikes. KAE not determined. }\end{array}$ & $\begin{array}{l}\text { Gd to Tdj } \\
\text { Gd and Tdj }\end{array}$ & $\leq 10 \%$, only Bt & $\begin{array}{l}\text { Ap, Zrn, Ttn, Aln. Growth of } \\
\text { Ep over Aln }\end{array}$ \\
\hline $\begin{array}{l}\text { TH - country rock } \\
\text { amphibolite }\end{array}$ & $\begin{array}{l}\text { Foliated, fine to medium grained } \\
\text { mafic amphibolite. Occurs as roof } \\
\text { pendants or xenoliths on various } \\
\text { granitoids. Contains } \mathrm{Hbl}, \mathrm{Pl}, \mathrm{Qtz} \text {, } \\
\text { Ttn, Ep and opaque minerals. Bt is } \\
\text { locally observed. }\end{array}$ & & & \\
\hline Gn1 - trondhjemitic gneiss & $\begin{array}{l}\text { Foliated to banded, medium } \\
\text { grained biotite tonalitic to } \\
\text { trondhjemitic orthogneiss. }\end{array}$ & & & \\
\hline Gn2 - qz dioritic gneiss & $\begin{array}{l}\text { Banded medium grained biotite- } \\
\text { hornblende-quartz-plagioclase } \\
\text { gneiss. With accessoryTtn, Ep, Aln, } \\
\text { Zrn, Ap and opaque minerals. }\end{array}$ & & & \\
\hline Gn3 - qz dioritic gneiss & $\begin{array}{l}\text { Banded and complexely folded } \\
\text { medium grained biotite- } \\
\text { hornblende-quartz-plagioclase } \\
\text { gneiss. With Ttn, Ep and opaque } \\
\text { minerals. }\end{array}$ & & & \\
\hline
\end{tabular}

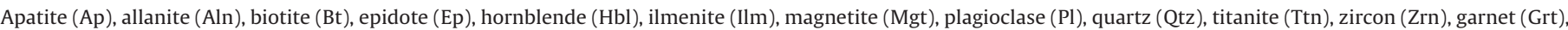
muscovite (Ms), diorite (Di), quartz diorite (Qz-Di), granodiorite (Gd), tonalite (To), trondhjemite (Tdj).

Campos and Carneiro, 2008; Ávila et al., 2010). Fig. 2 shows the location of the samples discussed in this work, along with a classification of some of the granitoid suites of the Mineiro Belt occurring at the southern edge of the Quadrilátero Ferrífero region, which is based in a repertory of unpublished field, whole rock geochemical, $\mathrm{U}-\mathrm{Pb}$ and $\mathrm{Nd}$-isotopic data obtained over the last decade by the first author of the present study. A synopsis of these data is presented in Table 1.

\section{Analytical methods}

Microprobe analyses of biotite, plagioclase and garnet were obtained at Universidade Federal de Minas Gerais, Belo Horizonte, Brazil using a Jeol JXA 8900 RL. The general operating procedures used a $15 \mathrm{kV}$ accelerating voltage and a $20 \mathrm{nA}$ beam current in conjunction with natural and synthetic minerals as standards. ICP-OES and ICP-MS measurements of major and trace elements 
(a)

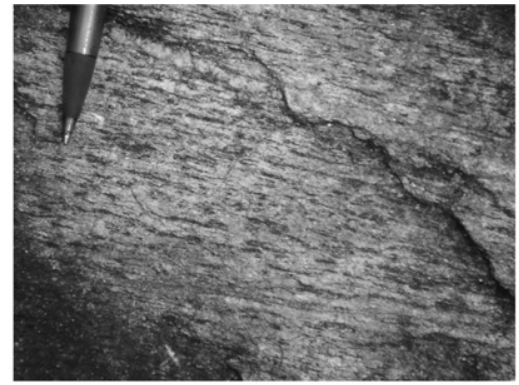

(c)

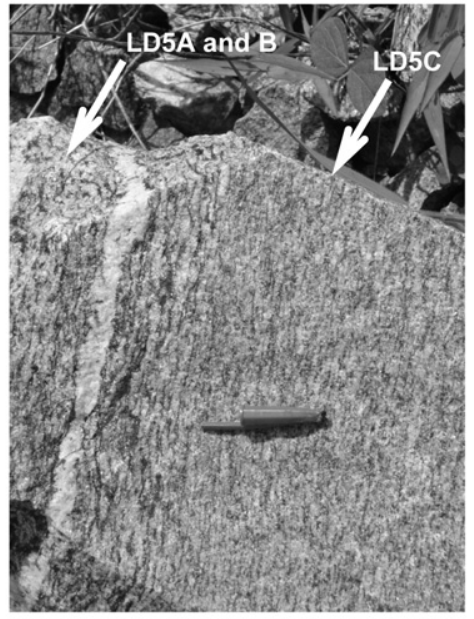

(b)

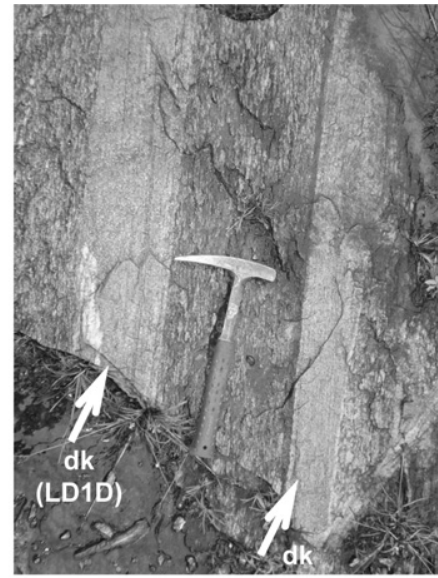

(d)

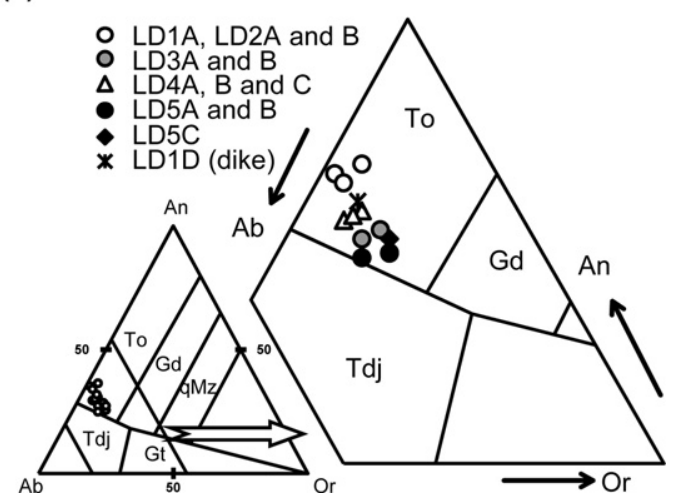

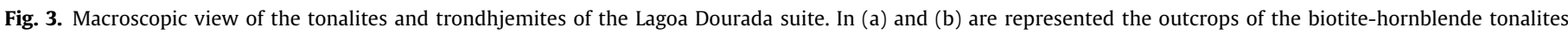

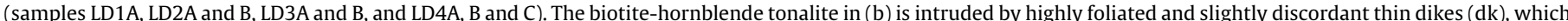

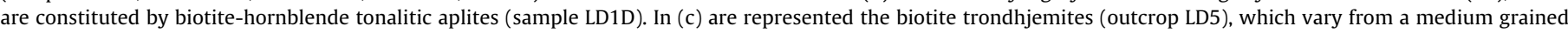

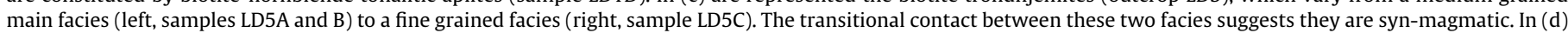

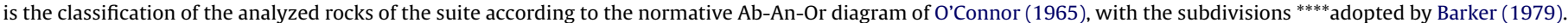
To: tonalite, Gd: granodiorite, Tdj: trondhjemite, Gt: granite, qMz: quartz monzonite. Chemical data from Table 5.

(a)

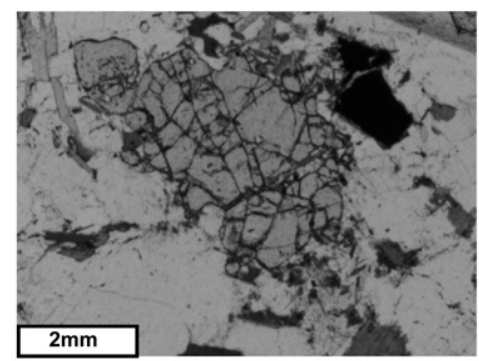

(b)

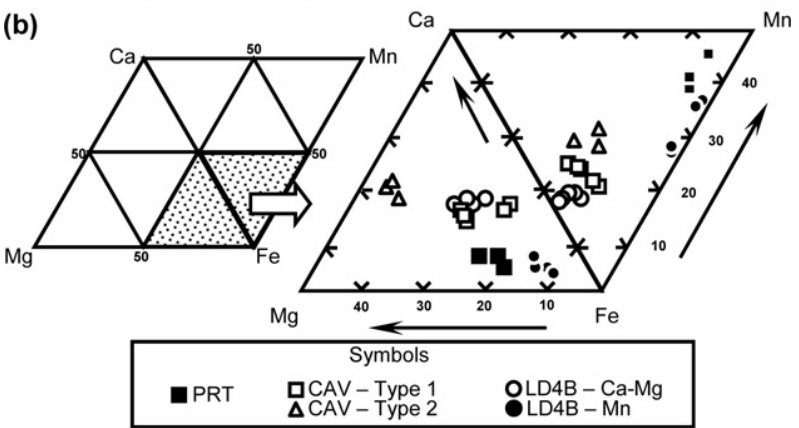

Fig. 4. (a) Textural feature of a garnet crystal from the hornblende-biotite tonalite LD4B (transmitted light). (b) Range of compositions of the different garnet crystals analyzed by electron microprobe (data from Table 2). The garnet compositions vary between $\mathrm{Ca}-\mathrm{Mg}$ - and $\mathrm{Mn}$-rich almandine. Also plotted for comparison are the compositions of the Mn-rich almandine from the Peñón Rosado S-type tonalite (PRT, Dahlquist et al., 2007) and phenocrysts of Ca-Mg almandine from the calcalkaline andesites and dacites of the Northern Pannonian Basin (CAV, types 1A and 1B, Harangi et al., 2001). were obtained on whole rock powders at ACTLABS and ACME laboratories (Canada) using a lithium metaborate/tetraborate fusion to digest the samples. Zircon U-Pb (ID-TIMS) and whole rock Sm-Nd isotopic analyses were made at the GEOTOP-UQAM, Montreal, Canada. The rocks for U-Pb geochronology were crushed, and heavy minerals were separated on a Wilfley table. The heavy minerals were further separated by the use of heavy liquids.

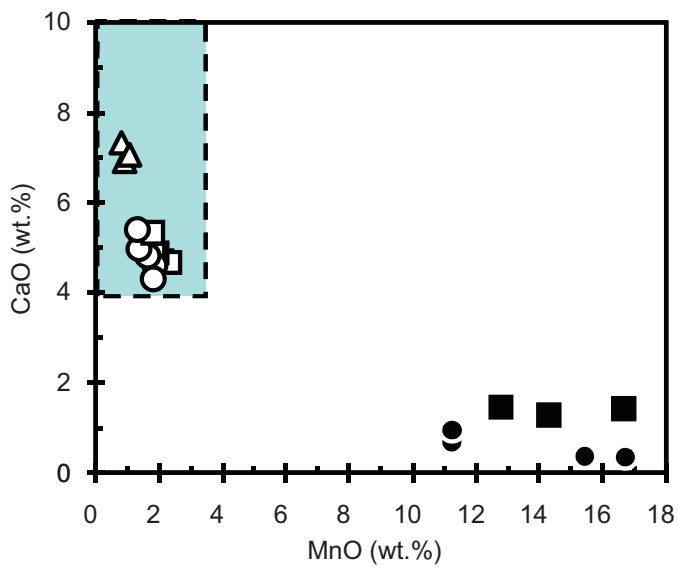

Fig. 5. Range of composition of the almandine garnets from the hornblende-biotite tonalite LD4B in terms of wt.\% $\mathrm{CaO}$ and MnO. Symbols as in Fig. 4. Grey field indicates range of composition of igneous garnets crystallized at high pressures from magmas derived from mantle and/or igneous crustal sources (Harangi et al., 2001). 
Table 2

Chemistry of minerals from the tonalite LD4B, Lagoa Dourada suite. Amphibole was not analyzed.

\begin{tabular}{|c|c|c|c|c|c|c|c|c|c|c|c|c|c|c|}
\hline \multirow{2}{*}{\multicolumn{2}{|c|}{$\begin{array}{l}\text { Biotite } \\
\text { Ox. }\end{array}$}} & \multicolumn{3}{|c|}{ Plagioclase } & \multicolumn{10}{|c|}{ Garnet } \\
\hline & & \multirow{2}{*}{$\begin{array}{l}\mathrm{Ox} . \\
\mathrm{SiO}_{2}\end{array}$} & \multirow{2}{*}{$\begin{array}{l}\text { core } \\
60.68\end{array}$} & \multirow{2}{*}{$\begin{array}{l}\text { bord } \\
63.78\end{array}$} & \multirow{2}{*}{$\begin{array}{l}\text { Ox. } \\
\mathrm{SiO}_{2}\end{array}$} & \multicolumn{3}{|c|}{$\mathrm{Ca}-\mathrm{Mg}$ almandine variety } & \multicolumn{6}{|c|}{ Mn almandine variety } \\
\hline $\mathrm{SiO}_{2}$ & 35.52 & & & & & 38.19 & 37.51 & 38.19 & 38.25 & 38.23 & 36.38 & 36.82 & 36.45 & 37.12 \\
\hline $\mathrm{TiO}_{2}$ & 1.57 & $\mathrm{TiO}_{2}$ & 0.00 & 0.01 & $\mathrm{TiO}_{2}$ & 0.08 & 0.08 & 0.06 & 0.02 & 0.08 & 0.02 & 0.02 & 0.02 & 0.07 \\
\hline $\mathrm{Al}_{2} \mathrm{O}_{3}$ & 16.79 & $\mathrm{Al}_{2} \mathrm{O}_{3}$ & 23.93 & 22.24 & $\mathrm{Al}_{2} \mathrm{O}_{3}$ & 21.69 & 21.67 & 21.60 & 21.75 & 21.34 & 20.71 & 20.88 & 20.71 & 21.03 \\
\hline $\mathrm{Cr} 2 \mathrm{O} 3$ & 0.01 & $\mathrm{FeO}_{\mathrm{t}}$ & 0.08 & 0.07 & $\mathrm{FeO}$ & 31.37 & 30.72 & 30.30 & 29.74 & 30.82 & 25.61 & 25.42 & 29.41 & 29.41 \\
\hline $\mathrm{FeO}_{\mathrm{t}}$ & 21.08 & $\mathrm{MnO}$ & 0.03 & 0.08 & $\mathrm{Cr}_{2} \mathrm{O}_{3}$ & 0.00 & 0.00 & 0.00 & 0.02 & 0.01 & 0.00 & 0.00 & 0.00 & 0.00 \\
\hline $\mathrm{MnO}$ & 0.20 & $\mathrm{MgO}$ & 0.00 & 0.01 & $\mathrm{MnO}$ & 1.88 & 1.82 & 1.62 & 1.37 & 1.32 & 16.73 & 15.43 & 11.24 & 11.25 \\
\hline $\mathrm{MgO}$ & 10.35 & $\mathrm{CaO}$ & 5.34 & 3.19 & $\mathrm{MgO}$ & 4.13 & 3.84 & 4.15 & 4.66 & 4.10 & 1.61 & 1.47 & 2.07 & 1.96 \\
\hline $\mathrm{CaO}$ & 0.01 & $\mathrm{Na}_{2} \mathrm{O}$ & 8.76 & 10.06 & $\mathrm{CaO}$ & 4.60 & 4.30 & 4.81 & 4.97 & 5.39 & 0.34 & 0.37 & 0.68 & 0.77 \\
\hline $\mathrm{Na}_{2} \mathrm{O}$ & 0.07 & $\mathrm{~K}_{2} \mathrm{O}$ & 0.08 & 0.06 & $\mathrm{Na}_{2} \mathrm{O}$ & 0.01 & 0.04 & 0.01 & 0.03 & 0.03 & 0.04 & 0.05 & 0.03 & 0.05 \\
\hline $\mathrm{K}_{2} \mathrm{O}$ & 9.32 & Total & 98.92 & 99.50 & $\mathrm{~K}_{2} \mathrm{O}$ & 0.02 & 0.01 & 0.01 & 0.01 & 0.02 & 0.00 & 0.00 & 0.00 & 0.00 \\
\hline $\mathrm{F}$ & 0.26 & $\mathrm{Si}$ & 2.727 & 2.833 & Total & 101.96 & 99.99 & 100.75 & 100.82 & 101.33 & 101.43 & 100.46 & 100.60 & 101.66 \\
\hline $\mathrm{Cl}$ & 0.04 & Al & 1.268 & 1.164 & $\mathrm{Si}$ & 5.946 & 5.957 & 6.004 & 5.982 & 5.979 & 5.867 & 5.984 & 5.899 & 5.944 \\
\hline Total & 95.22 & $\mathrm{Fe}_{t}$ & 0.003 & 0.003 & $\mathrm{Al}^{\mathrm{IV}}$ & 0.054 & 0.043 & 0.000 & 0.018 & 0.021 & 0.133 & 0.016 & 0.101 & 0.056 \\
\hline $\mathrm{Si}$ & 5.489 & $\mathrm{Ca}$ & 0.257 & 0.152 & $\mathrm{Al}^{\mathrm{VI}}$ & 3.927 & 4.012 & 4.002 & 3.992 & 3.912 & 3.802 & 3.983 & 3.850 & 3.914 \\
\hline $\mathrm{Al}$ & 3.059 & $\mathrm{Na}$ & 0.764 & 0.866 & $\mathrm{Fe}^{3+}$ & 0.115 & 0.024 & 0.000 & 0.030 & 0.102 & 0.341 & 0.044 & 0.255 & 0.139 \\
\hline $\mathrm{Ti}$ & 0.183 & K & 0.005 & 0.004 & $\mathrm{Ti}$ & 0.009 & 0.010 & 0.007 & 0.003 & 0.009 & 0.002 & 0.002 & 0.002 & 0.009 \\
\hline $\mathrm{Cr}$ & 0.001 & Total & 5.023 & 5.020 & $\mathrm{Cr}$ & 0.000 & 0.000 & 0.000 & 0.002 & 0.001 & 0.000 & 0.000 & 0.000 & 0.000 \\
\hline $\mathrm{Fe}_{t}$ & 2.724 & $\% A n$ & 25.1 & 14.9 & $\mathrm{Mg}$ & 0.958 & 0.908 & 0.972 & 1.087 & 0.956 & 0.387 & 0.356 & 0.500 & 0.467 \\
\hline Mn & 0.026 & $\% A b$ & 74.5 & 84.8 & $\mathrm{Fe}^{2+}$ & 3.969 & 4.055 & 3.984 & 3.860 & 3.929 & 3.112 & 3.411 & 3.725 & 3.800 \\
\hline $\mathrm{Mg}$ & 2.385 & $\% \mathrm{Or}$ & 0.46 & 0.35 & Mn & 0.248 & 0.245 & 0.216 & 0.181 & 0.174 & 2.284 & 2.124 & 1.541 & 1.526 \\
\hline $\mathrm{Ca}$ & 0.002 & & & & $\mathrm{Ca}$ & 0.767 & 0.732 & 0.810 & 0.833 & 0.904 & 0.059 & 0.065 & 0.119 & 0.132 \\
\hline $\mathrm{Na}$ & 0.020 & & & & $\mathrm{Na}$ & 0.004 & 0.011 & 0.003 & 0.010 & 0.009 & 0.014 & 0.015 & 0.008 & 0.014 \\
\hline K & 1.837 & & & & K & 0.003 & 0.002 & 0.001 & 0.002 & 0.004 & 0.000 & 0.000 & 0.000 & 0.001 \\
\hline Total & 15.726 & & & & Total & 16.000 & 16.000 & 16.000 & 16.000 & 16.000 & 16.000 & 16.000 & 16.000 & 16.000 \\
\hline $\mathrm{F}$ & 0.125 & & & & Alm & 66.8 & 68.3 & 66.6 & 64.8 & 65.9 & 53.3 & 57.3 & 63.3 & 64.1 \\
\hline $\mathrm{Mg} / \mathrm{Mg}+\mathrm{Fe}_{t}$ & 0.47 & & & & Esp & 4.2 & 4.1 & 3.6 & 3.0 & 2.9 & 39.1 & 35.7 & 26.2 & 25.8 \\
\hline $\mathrm{FeO} / \mathrm{MgO}$ & 2.04 & & & & Pyr & 16.1 & 15.3 & 16.3 & 18.2 & 16.0 & 6.6 & 6.0 & 8.5 & 7.9 \\
\hline & & & & & Gross & 12.9 & 12.3 & 13.5 & 14.0 & 15.2 & 1.0 & 1.1 & 2.0 & 2.2 \\
\hline
\end{tabular}

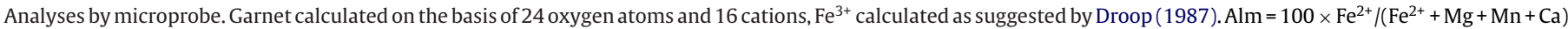

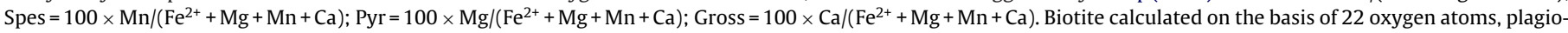
clase on the basis of 8 oxygen atoms.

Zircons were separated into magnetic and nonmagnetic fractions using a Franz magnetic separator. Selected individual grains were abraded to minimize the effects of $\mathrm{Pb}$ loss or to remove metamorphic overgrowths. The selected grains were weighed, mixed with a ${ }^{205} \mathrm{~Pb}-{ }^{233} \mathrm{U}-{ }^{235} \mathrm{U}$ spike and subsequently dissolved in an HF$\mathrm{HNO}_{3}$ solution. Uranium and lead were separated using an anion exchange resin and the resulting uranium and lead fraction was loaded on single Re filaments and analyzed using a solid source VG
Sector mass spectrometer with a Daly detector. The isotopic ratios were corrected for fractionation, spike, blank, and initial common lead, and regressions were calculated using IsoplotEX. Samples for $\mathrm{Sm}-\mathrm{Nd}$ isotopic analyses were dissolved in a $\mathrm{HF}-\mathrm{HNO}_{3}$ mixture in high-pressure Teflon vessels. A ${ }^{150} \mathrm{Nd}-{ }^{149} \mathrm{Sm}$ tracer was added to determine Nd and Sm concentrations. The REE were then purified by cation exchange chromatography, and Sm and Nd were subsequently separated following the procedure of Richard et al. (1976).

Table 3

$\mathrm{U}-\mathrm{Pb}$ isotopic data for rocks of the Lagoa Dourada suite.

\begin{tabular}{|c|c|c|c|c|c|c|c|c|c|c|c|c|c|c|c|c|c|c|c|c|}
\hline \multirow[t]{2}{*}{ Fraction $^{\mathrm{a}}$} & \multirow{2}{*}{$\begin{array}{l}\text { Weight } \\
\text { (mg) }\end{array}$} & \multirow{2}{*}{$\begin{array}{l}\mathrm{U} \\
(\mathrm{ppm})\end{array}$} & \multirow{2}{*}{$\begin{array}{l}\text { Pbrad } \\
(\mathrm{ppm})\end{array}$} & \multirow{2}{*}{$\begin{array}{l}\text { Pbcom }^{\mathrm{b}} \\
\text { (pg) }\end{array}$} & \multirow[t]{2}{*}{$\mathrm{Th} / \mathrm{U}$} & \multirow{2}{*}{$\begin{array}{l}{ }^{206} \mathrm{~Pb} / \\
{ }^{204} \mathrm{~Pb}^{\mathrm{c}}\end{array}$} & \multicolumn{6}{|c|}{ Isotopic ratios } & \multicolumn{8}{|l|}{ Ages } \\
\hline & & & & & & & $\begin{array}{l}{ }^{206} \mathrm{~Pb} / \\
{ }^{238} \mathrm{U}^{\mathrm{d}}\end{array}$ & $\begin{array}{l} \pm 1 \sigma \\
\%\end{array}$ & $\begin{array}{l}{ }^{207} \mathrm{~Pb} / \\
{ }^{235} \mathrm{U}^{\mathrm{d}}\end{array}$ & $\pm 1 \sigma \%$ & $\begin{array}{l}{ }^{207} \mathrm{~Pb} / \\
{ }^{206} \mathrm{~Pb}^{\mathrm{d}}\end{array}$ & $\pm 1 \sigma \%$ & $\begin{array}{l}{ }^{206} \mathrm{~Pb} / \\
{ }^{238} \mathrm{U}\end{array}$ & $\pm 2 \sigma$ & $\begin{array}{l}{ }^{207} \mathrm{~Pb} / \\
{ }^{235} \mathrm{U}\end{array}$ & $\pm 2 \sigma$ & $\begin{array}{l}{ }^{207} \mathrm{~Pb} / \\
{ }^{206} \mathrm{~Pb}\end{array}$ & $\pm 2 \sigma$ & Disc. & $\sigma$ \\
\hline \multicolumn{21}{|c|}{ Sample LD5A } \\
\hline$A(1), t, i c$ & 0.0010 & 363 & 169 & 3.0 & 0.353 & 3348 & 0.4382 & 0.16 & 9.104 & 0.17 & 0.15069 & 0.05 & 2342.6 & 6.2 & 2348.6 & 3.1 & 2353.7 & 0.9 & 0.6 & 0.95 \\
\hline B (1),sp,ic & 0.0018 & 248 & 112 & 2.8 & 0.291 & 4614 & 0.4239 & 0.18 & 8.754 & 0.20 & 0.14979 & 0.05 & 2278.0 & 7.0 & 2312.7 & 3.6 & 2343.5 & 0.8 & 3.3 & 0.97 \\
\hline C (1),f,lp,ic & 0.0010 & 303 & 139 & 2.9 & 0.273 & 2871 & 0.4325 & 0.15 & 8.972 & 0.17 & 0.15047 & 0.10 & 2316.8 & 6.0 & 2335.2 & 3.1 & 2351.3 & 1.7 & 1.7 & 0.81 \\
\hline \multicolumn{21}{|c|}{ Sample LD4A } \\
\hline $\mathrm{A}(1), \mathrm{t}, \mathrm{br}$ & 0.0010 & 518 & 235 & 4.1 & 0.246 & 3352 & 0.4326 & 0.17 & 8.922 & 0.19 & 0.14957 & 0.06 & 2317.6 & 6.8 & 2330.1 & 3.4 & 2341.0 & 1.0 & 1.2 & 0.95 \\
\hline $\mathrm{B}(1), \mathrm{t}, \mathrm{br}$ & 0.0010 & 314 & 145 & 3.2 & 0.313 & 2622 & 0.4331 & 0.16 & 8.934 & 0.18 & 0.14961 & 0.05 & 2319.7 & 6.2 & 2331.3 & 3.2 & 2341.5 & 0.8 & 1.1 & 0.96 \\
\hline$C(1), \mathrm{lp}, \mathrm{br}$ & 0.0010 & 349 & 159 & 4.3 & 0.256 & 2183 & 0.4318 & 0.23 & 8.922 & 0.23 & 0.14987 & 0.10 & 2313.6 & 9.1 & 2330.1 & 4.2 & 2344.5 & 1.7 & 1.6 & 0.91 \\
\hline $\mathrm{D}(1), \mathrm{f}, \mathrm{l}, \mathrm{br}$ & 0.0010 & 306 & 142 & 4.2 & 0.309 & 2219 & 0.4368 & 0.16 & 9.055 & 0.18 & 0.15036 & 0.06 & 2336.2 & 6.3 & 2343.6 & 3.2 & 2350.0 & 1.0 & 0.7 & 0.95 \\
\hline $\mathrm{E}(1), \mathrm{t}, \mathrm{ic}$ & 0.0020 & 248 & 116 & 5.4 & 0.312 & 2552 & 0.4382 & 0.15 & 9.083 & 0.17 & 0.15035 & 0.05 & 2342.4 & 5.8 & 2346.4 & 3.0 & 2349.9 & 0.9 & 0.4 & 0.95 \\
\hline
\end{tabular}

a All fractions are zircon. Number in parentheses is the number of grains in the analysis. Morphology: ic - colorless, pk - pink, br - brown, $\mathrm{t}-\mathrm{tip}, \mathrm{f}-\mathrm{fragment}$, sp - short prisme, lp - long prism.

b Total common lead (spike, blank and mineral).

c Measured ratio corrected for Pb fractionation.

d Corrected for $\mathrm{Pb}$ fractionation, blank $(\mathrm{Pb}=4 \mathrm{pg}, \mathrm{U}=0.5 \mathrm{pg})$, spike and initial common lead. 

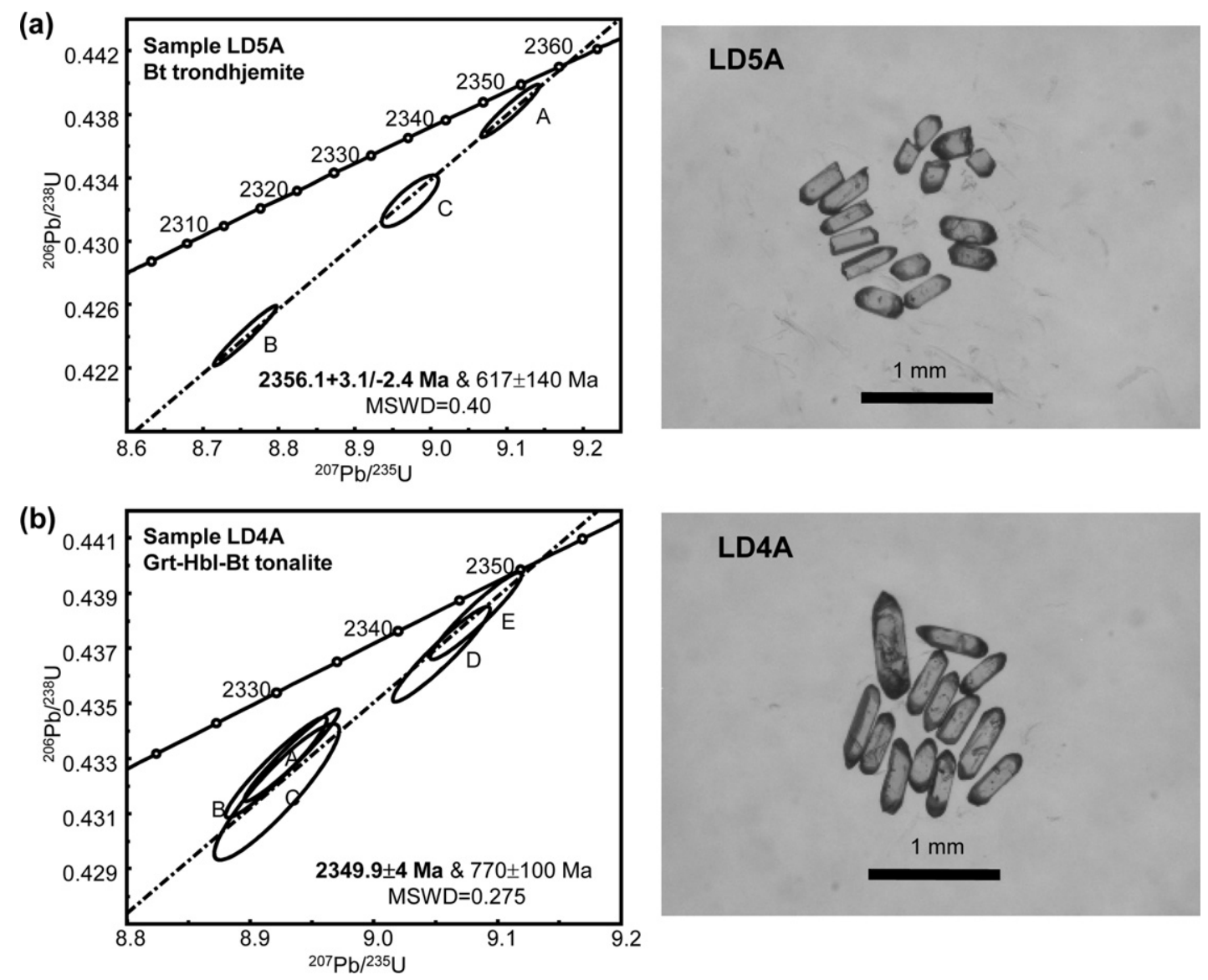

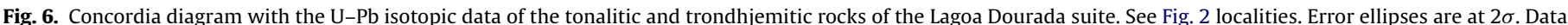
from Table 3.

The total procedural blanks are less than $150 \mathrm{pg}$. The Sm and Nd analyses were done using a triple filament assembly in a VG-Sector54 mass spectrometer. The Nd and Sm isotopes were measured in dynamic and static modes, respectively. Repeated measurements of the JNdi-1 Nd standard (Tanaka et al., 2000) yielded a value of ${ }^{143} \mathrm{Nd} /{ }^{144} \mathrm{Nd}=0.512106 \pm 7(n=37)$. The $\mathrm{Sm}$ and Nd concentrations and the ${ }^{147} \mathrm{Sm} /{ }^{144} \mathrm{Nd}$ ratios have an accuracy of $0.5 \%$ that corresponds to an average error on the initial $\varepsilon_{\mathrm{Nd}}$ value of \pm 0.5 epsilon units.

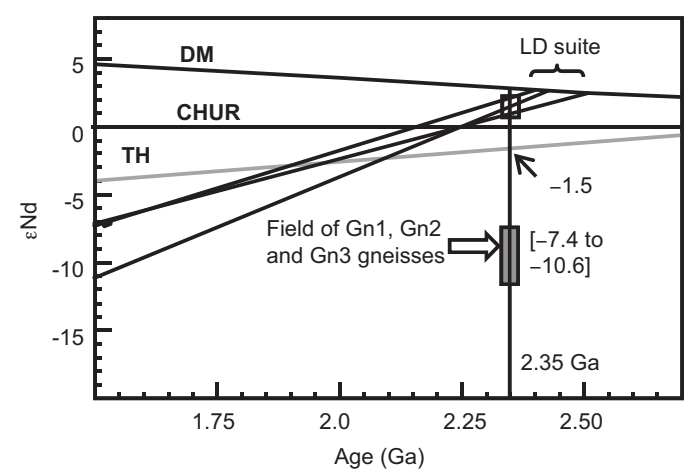

Fig. 7. $\varepsilon_{\mathrm{Nd}}$ versus age diagram showing the Nd-isotopic evolution of the rocks of the Lagoa Dourada suite. The line TH represents the Nd-isotopic evolution of the country rock amphibolite, and the bar indicates the field of the three gneisses (Gn1, $\mathrm{Gn} 2$ and $\mathrm{Gn} 3$ ). These latter samples represent the Nd-isotopic evolution of older mafic and intermediate-to-felsic crustal materials from the surrounding terrains. See Fig. 2 for the sample localities. Data from Table 4. Typical error is $0.5 \varepsilon_{\mathrm{Nd}}$. DM and CHUR denote depleted mantle (after DePaolo, 1981) and chondritic uniform reservoir, respectively.

\section{Sampling and petrography}

The collected granitoids came from five work stations of fresh, well exposed outcrops of moderate to highly deformed tonalitic and/or trondhjemitic rocks. The outcrops are all in the neighborhood of the town of Lagoa Dourada (Figs. 1 and 2, work stations labeled LD1 to LD5), contain similar petrological assemblages and are defined in this work as the Lagoa Dourada suite. The granitoids and the surrounding country rocks were metamorphosed to low-amphibolite facies metamorphism, but the prefix metais suppressed in the subsequent discussions for simplicity. The granitoids (Fig. 3a-c) are medium grained, foliated to gneissic, encompassing biotite-hornblende tonalites with $\sim 10 \%$ up to $25 \%$ mafic mineral content (work stations LD1 to LD4) to biotite trondhjemites (LD5 station). All the rock-types occupy the tonalitic field in the normative Ab-An-Or classification diagram, with the more felsic lying closer to the tonalite/trondhjemite boundary line (Fig. 3d). The biotite trondhjemites from work station LD5 include the main medium grained phase of the outcrop (samples LD5A and LD5B) and a finer grained trondhjemitic phase (sample LD5C). The observed transitional contact between these two facies (Fig. 3c), suggests that the finer grained phase was emplaced as a syn-magmatic batch of magma during the evolution of the suite. In contrast, at the other work stations, the medium grained biotite-hornblende tonalites are intruded by thin dikes of highly foliated fine-grained tonalitic aplites. Sample LD1D represents one of these dikes (Fig. 3b), which is petrographically similar to its host. In this case however, the dikes are interpreted as being emplaced as post-magmatic and pre- to syn-deformational phases. 
(a)

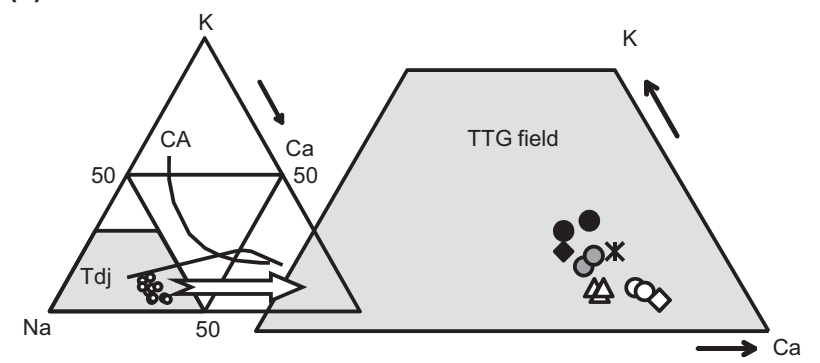

(c)

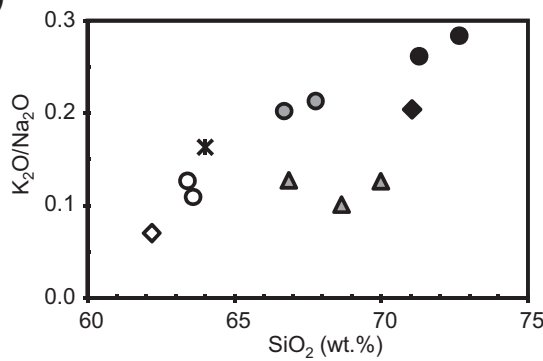

(b)

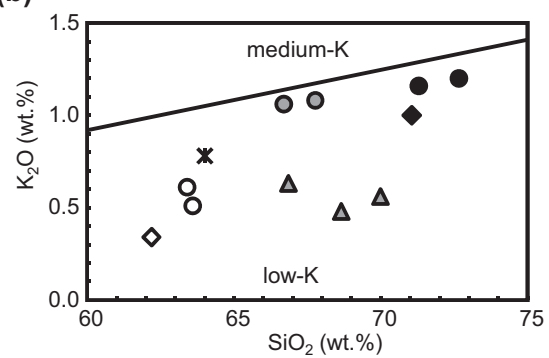

(d)

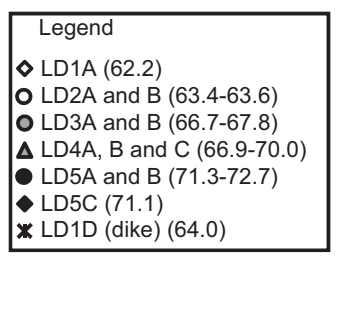

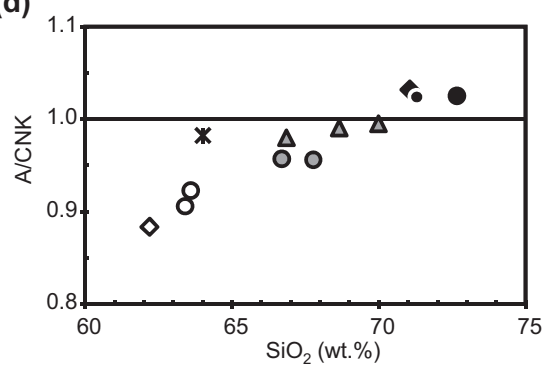

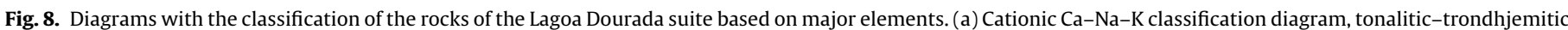

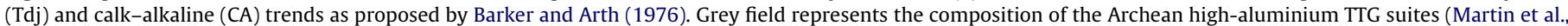

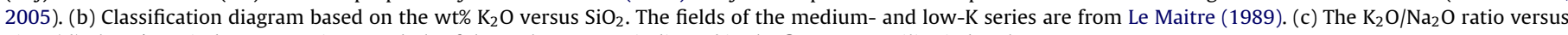
$\mathrm{SiO}_{2}$. (d) The A/CNK index versus $\mathrm{SiO}_{2}$. Symbols of the rock types are indicated in the figure, wt.\% silica in brackets.

All the granitoids contain zircon, apatite and allanite as accessory minerals, the latter with epidote coronas. Traces of K-feldspar are found in the biotite trondhjemites. In addition, magnetite is also a distinctive accessory mineral. Garnet and pyrrhotite are found in some specimens, the former in the tonalites of the work stations LD1 and LD4, and in the tonalitic aplite dike LD1D. Results of microprobe analyses of plagioclase, biotite and garnet from the tonalite LD4B are presented in Table 2. The plagioclase is oligoclase $\left(A n_{29}\right.$ to $\left.A n_{15}\right)$ and the biotite is a ferriferous variety, with $\mathrm{Mg} / \mathrm{Mg}+\mathrm{Fe}_{t}$ from 0.45 to 0.48 . Garnet shows two distinct compositions (Fig. 4a and b): (i) a Ca-Mg almandine (average Alm 66.5 Spess $_{3.6} \operatorname{Pyr}_{16.4}$ Gross $_{13.6}$ ); and (ii) a manganese rich type (average Alm $_{59.5}$ Spess $_{31.7}$ Pyr $_{7.2}$ Gross $_{1.6}$ ). The Ca-Mg almandine plot in the compositional field of igneous garnets crystallized in magmas derived from mantle and/or igneous crustal sources (Fig. 5; Harangi et al., 2001), whereas the Mn-rich almandine are likely associated with post-magmatic recrystallization of the suite at low pressure (Dahlquist et al., 2007).

\section{U-Pb geochronology}

Two facies of the Lagoa Dourada suite were chosen for U-Pb IDTIMS zircon geochronology: a garnet hornblende-biotite tonalite (LD4A), and a biotite trondhjemite (LD5A). The results are presented in Table 3. Zircons from both samples are very similar, ranging from colorless to brown, short to long prismatic, bipyramidal crystals (Fig. 6). A regression of three zircon fractions from the biotite trondhjemite LD5A yielded a best fit line with an upper intercept age of $2356.1+3.1 /-2.4$ Ma (MSWD =0.40). Similarly, a regression of five zircon fractions from the hornblende-biotite tonalite LD4A yielded an upper intercept age of $2349.9 \pm 4 \mathrm{Ma}$ (MSWD =0.275; Fig. 6). These ages are nearly identical within error and indicate that both samples crystallized at ca. $2350 \mathrm{Ma}$. The ages are older than the generally accepted ca. 2.2-2.1 Ga age range for Trans-Amazonian pre- to syn-orogenic felsic plutonic suites of the southern Quadrilátero Ferrífero region (Noce et al., 2000; Silva et al., 2002; Noce et al., 2007a; Campos and Carneiro, 2008; Ávila et al.,
2010). Thus the Lagoa Dourada suite constitutes an earlier event of felsic plutonic magmatic activity in the scope of the Mineiro belt.

\section{Nd isotope composition}

The Nd isotope compositions of selected samples of the Lagoa Dourada suite are presented in Table 4 . This includes a biotitehornblende tonalite (LD3A), a hornblende-biotite tonalite (LD4B) and a biotite trondhjemite (LD5B). Table 4 also includes four representative samples of the enclosing country rocks sampled next to the Congonhas lineament (Fig. 2). These rocks are a metabasaltic tholeiitic amphibolite (sample TH), a trondhjemitic gneiss (sample Gn1) and two samples of quartz dioritic gneisses (samples Gn2 and $\mathrm{Gn} 3$, see Fig. 2 for locations of the samples). The results for all the analyzed rocks are presented in the $\varepsilon_{\mathrm{Nd}}$ versus time diagram in Fig. 7. The Nd isotope data of the rocks of the Lagoa Dourada suite yielded $T_{\mathrm{DM}}$ ages ranging from 2.4 to $2.5 \mathrm{Ga}$ and $\varepsilon_{\mathrm{Nd}}(t=2350 \mathrm{Ma}) \mathrm{val}-$ ues of +1.0 to +2.1 (Fig. 7). The amphibolite and the trondhjemitic and quartz-dioritic gneisses yielded $\varepsilon_{\mathrm{Nd}}(t=2350 \mathrm{Ma})$ values of -1.5 , $-7.4,-10.6$ and -7.8 respectively (Fig. 7 ). Calculated $T_{\mathrm{DM}}$ ages of the felsic gneisses yielded values from 2.9 to $3.3 \mathrm{Ga}$ (Table 4 ). These data suggest that the parental magmas of the Lagoa Dourada suite were somewhat juvenile, with a slightly depleted Nd-isotopic signature of its source rock. This rules out any significant contribution from the older country rocks such as the tholeiitic amphibolite or the quartz-dioritic and/or trondhjemitic gneisses, all of which have distinctively negative $\varepsilon_{\mathrm{Nd}}$ values at the time of crystallization of the Lagoa Dourada suite ca. 2350 Ma.

\section{Whole rock geochemistry}

\subsection{Major and trace elements}

Chemical analyses of the Lagoa Dourada suite are given in Table 5. The biotite-hornblende to hornblende-biotite tonalites, and the biotite trondhjemites can be grouped as a progression from: (i) low silica tonalites (LD1A, LD2A, LD2B and the aplitic tonalite dike LD1D, all within the range of $62.2-64 \mathrm{wt} . \% \mathrm{SiO}_{2}$ ); 

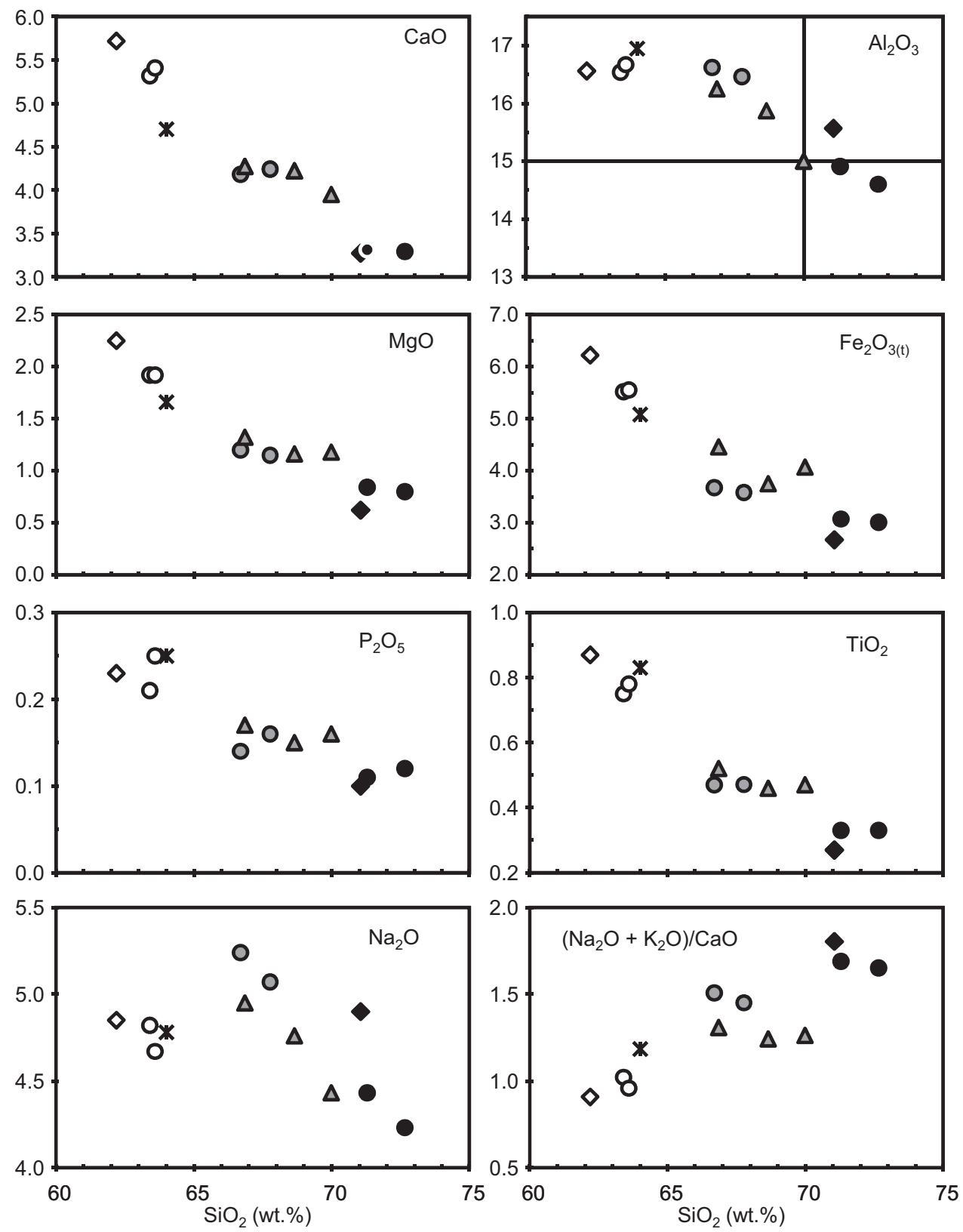

Fig. 9. Harker diagrams for the major elements to the rocks of the Lagoa Dourada suite. Legend as in Fig. 8. Oxydes in wt.\%.

(ii) to medium silica tonalites (LD3A, LD3B, LD4A, B and C with 66.7-70.0 wt.\% $\mathrm{SiO}_{2}$ ); and (iii) to high silica trondhjemites (LD5A, LD5B and the syn-magmatic finer grained biotite trondhjemite facies LD5C, all three samples with 71.3-72.7 wt.\% $\mathrm{SiO}_{2}$ ). General classifications based on the major elements are presented in Fig. 8. The Lagoa Dourada suite is defined as a metaluminous to slightly peraluminous, intermediate to felsic $\left(62-73 \% \mathrm{SiO}_{2}\right)$, low-K, TTG suite (Fig. 8a-d). More felsic members of the suite show slightly higher potassium contents (up to $1.2 \mathrm{wt} . \% \mathrm{~K}_{2} \mathrm{O}$ ) and $\mathrm{A} / \mathrm{CNK}$ ratios $\left(\mathrm{A} / \mathrm{CNK}=\mathrm{mol} \mathrm{Al}_{2} \mathrm{O}_{3} / \mathrm{CaO}+\mathrm{Na}_{2} \mathrm{O}+\mathrm{K}_{2} \mathrm{O}\right.$, up to 1.03$)$.

Overall, the three groups of rocks of the Lagoa Dourada suite show coherent trends of negative correlation of silica with the major oxides $\mathrm{CaO}, \mathrm{Al}_{2} \mathrm{O}_{3}, \mathrm{MgO}, \mathrm{Fe}_{2} \mathrm{O}_{3}, \mathrm{P}_{2} \mathrm{O}_{5}$ and $\mathrm{TiO}_{2}$, and with the trace elements such as Sr, Y, V, Sc and $\mathrm{Zr}$ (Figs. 9 and 10). The wt.\% $\mathrm{Na}_{2} \mathrm{O}$ and the $\mathrm{Nb}$ content show somewhat scattered distributions, but trend to lower values in the most siliceous rocks. The general positive correlation of silica with $\mathrm{K}_{2} \mathrm{O}$ (Fig. 8b) is accompanied by similar behavior of the trace elements $\mathrm{Rb}, \mathrm{Ba}$, Th and U (Fig. 10). In comparison with average compositions of TTG suites (Barker, 1979; Drummond and Defant, 1990; Martin, 1999; Smithies, 2000; Condie, 2005; Martin et al., 2005), the rocks of the Lagoa Dourada suite can be classified as a high-aluminium TTG suite; with $\mathrm{Al}_{2} \mathrm{O}_{3} \geq 15$ at $70 \% \mathrm{SiO}_{2}$, low $\mathrm{Rb}$ (generally $\leq 30 \mathrm{ppm}$ ), $\mathrm{Ba}(\leq 244 \mathrm{ppm}), \mathrm{Th}(\leq 2.6 \mathrm{ppm}), \mathrm{U}(\leq 1.1 \mathrm{ppm}), \mathrm{Y}(5-11 \mathrm{ppm})$ and $\mathrm{Nb}$ (5-8 ppm), and moderately high $\mathrm{Sr}(323-466 \mathrm{ppm})$. With respect to the trondhjemite definition proposed by Barker (1979), the rocks of the Lagoa Dourada suite with $>68$ wt.\% $\mathrm{SiO}_{2}$ are Ca-rich trondhjemites (with 3.3-4.2 wt.\% $\mathrm{CaO}$ compared to typical values of 1.5-3.0\%). The $\mathrm{FeO}^{*} / \mathrm{MgO}$ ratio of these rocks (2.9-3.4) are comparable to average ratios for trondhjemites (2-3; Barker, 1979; FeO* $\left.\left[\mathrm{FeO}^{*}=0.9 * \mathrm{Fe}_{2} \mathrm{O}_{3(t)}\right]\right)$. The high silica biotite trondhjemites LD5A, B and $C$ tend to form a coherent group in both major and trace element diagrams (Figs. 3 and 8-10). The biotite-hornblende tonalitic aplite dike LD1D (Fig. 3) has a major element chemical composition similar to that of the low silica tonalites, but the aplite is consistently more concentrated in $\mathrm{Sr}, \mathrm{Rb}, \mathrm{Ba}, \mathrm{Th}, \mathrm{U}$ and $\mathrm{V}$ and less 

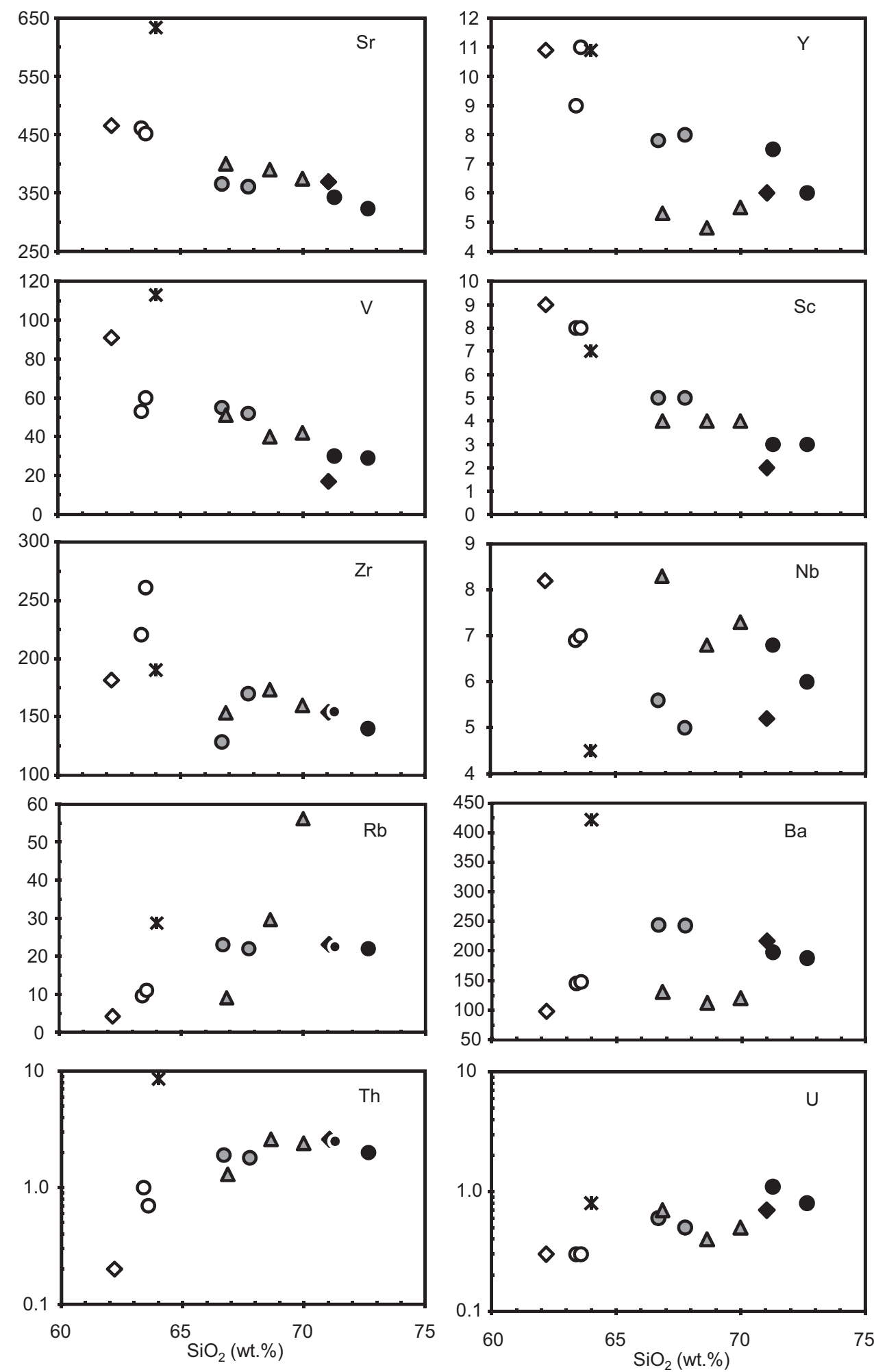

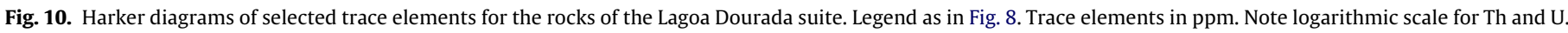

concentrated in $\mathrm{Nb}$ (Figs. 8-10; Y, Zr and Sc concentrations are similar).

\subsection{Rare earth elements}

Chondrite-normalized REE diagrams of the Lagoa Dourada suite are presented in Fig. 11. The Lagoa Dourada suite, like most TTG suites, have low heavy REE contents ( $\mathrm{Yb} \leq 1.0 \mathrm{ppm})$, high light/heavy REE ratios $\left(\mathrm{La}_{\mathrm{N}} / \mathrm{Yb}_{\mathrm{N}} \geq 10\right)$, and positive europium anomalies, although for the latter attribute this is not true for all TTG suites (Condie, 2005; Martin et al., 2005). Correlations of $\mathrm{SiO}_{2}$ with $\mathrm{La}$ and $\mathrm{Yb}$, and with light/heavy REE and with $\mathrm{Eu} / \mathrm{Eu}^{*}$ ratios are presented in Fig. 12. La and Yb show a steady-state behavior for the light REE and a somewhat negative correlation 
(a)

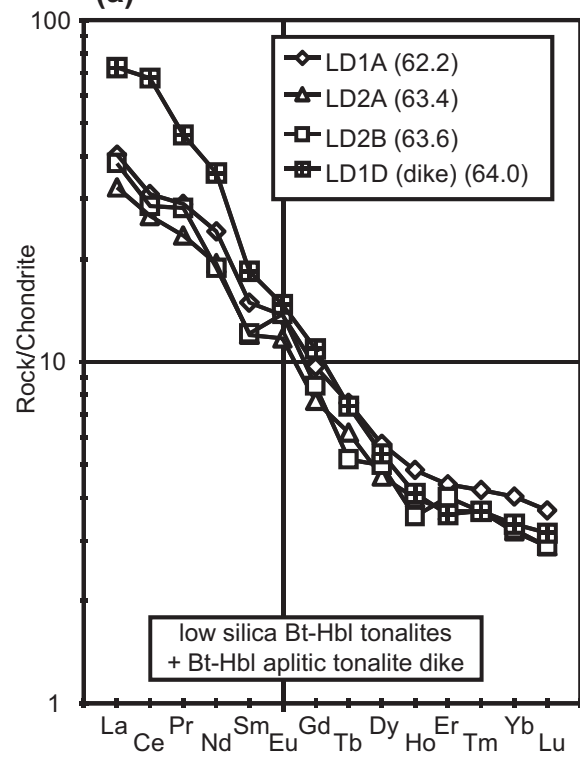

(b)

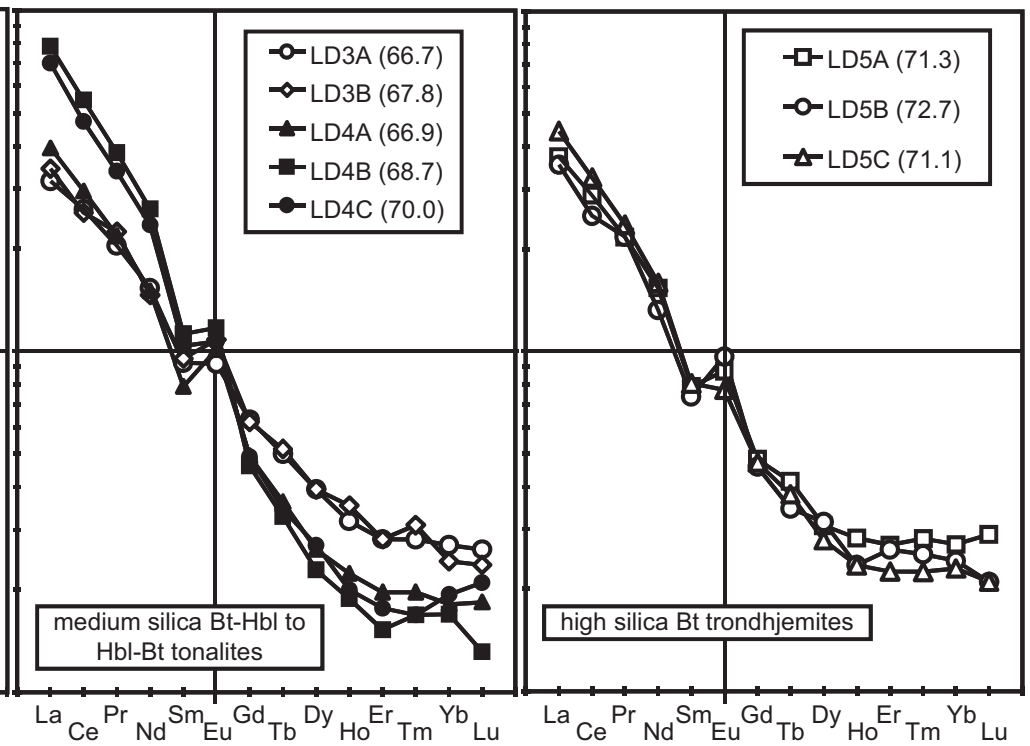

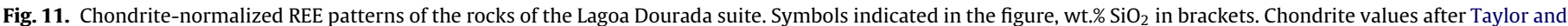
McLennan (1985).

between the heavy REE and silica (Fig. 12a and b), leading to the more siliceous samples having slightly higher light/heavy REE ratios (Figs. 11c and 12 ). The Eu/Eu* ratios increase with increasing silica content (Fig. 12d). Tonalites LD4 B and C have higher light REE and lower heavy REE contents compared to the other tonalites with equivalent wt.\% $\mathrm{SiO}_{2}$ (Fig. 12a and b). This results in a higher degree of light/heavy REE fractionation (Fig. 12c) and the crossing chondrite-normalized REE profiles seen in Fig. 11b. The biotite-hornblende aplitic tonalite dike LD1D has higher light and middle REE contents when compared to the other low silica tonalites, resulting in a higher $(\mathrm{La} / \mathrm{Yb})_{\mathrm{N}}$ ratio and no Eu/Eu* anomaly (Figs. $11 \mathrm{a}$ and $12 \mathrm{a}-\mathrm{d}$ ).

\subsection{Primitive mantle-normalized diagrams}

Primitive mantle-normalized multi-element diagrams of the Lagoa Dourada suite are presented in Fig. 13. Also plotted for comparison is the average composition of the Proterozoic TTG suites compiled by Condie (2005). These diagrams show the following common characteristics between the Lagoa Dourada suite and the Proterozoic TTG's: (i) negative slopes between the LIL and the highfield-strength (HFS) elements; (ii) negative spikes for $\mathrm{Nb}-\mathrm{Ta}, \mathrm{P}$ and Ti relative to their neighboring elements; and (iii) lower than tholeiitic values of $\mathrm{Y}$ and $\mathrm{Yb}$ (not shown in Fig. 13). In contrast, the Lagoa Dourada suite is consistently depleted in LIL elements $(\mathrm{K}, \mathrm{Rb}, \mathrm{Ba}$, (a)

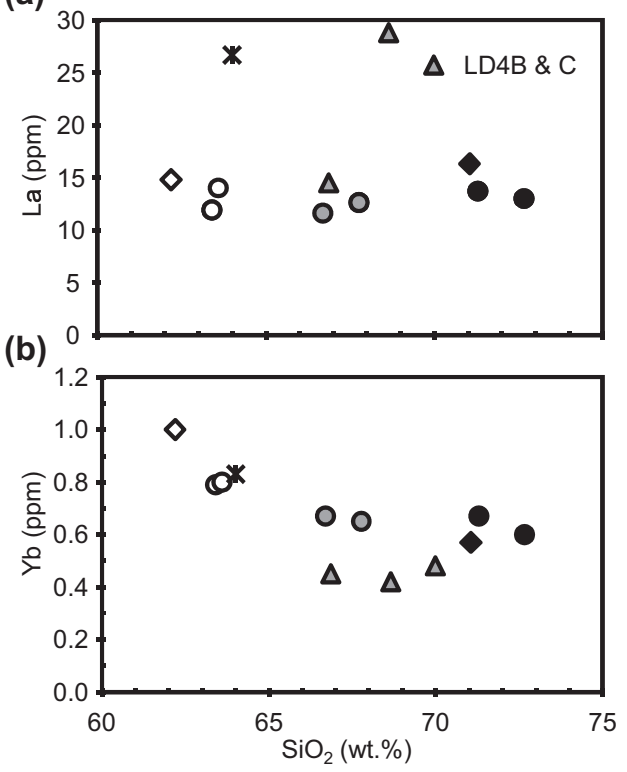

(c)

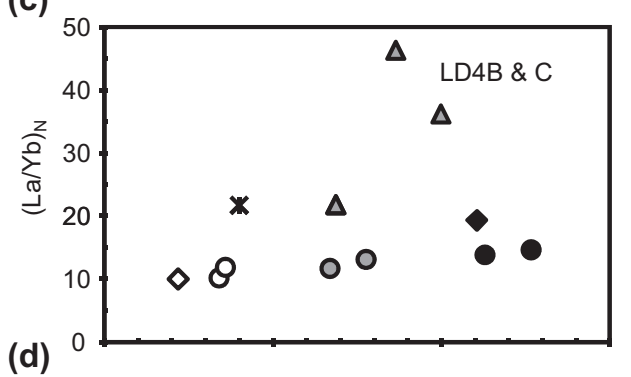

(d)

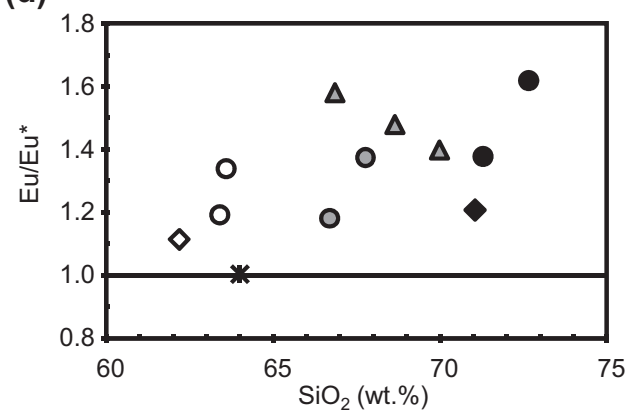

Fig. 12. Harker diagrams for $\mathrm{La}(\mathrm{a})$ and $\mathrm{Yb}(\mathrm{b})$; and for the $(\mathrm{La} / \mathrm{Yb})_{\mathrm{N}}(\mathrm{c})$ and $\mathrm{Eu} / \mathrm{Eu}^{*}(\mathrm{~d})$ ratios to the rocks of the Lagoa Dourada suite. Legend as in Fig. 8 . 

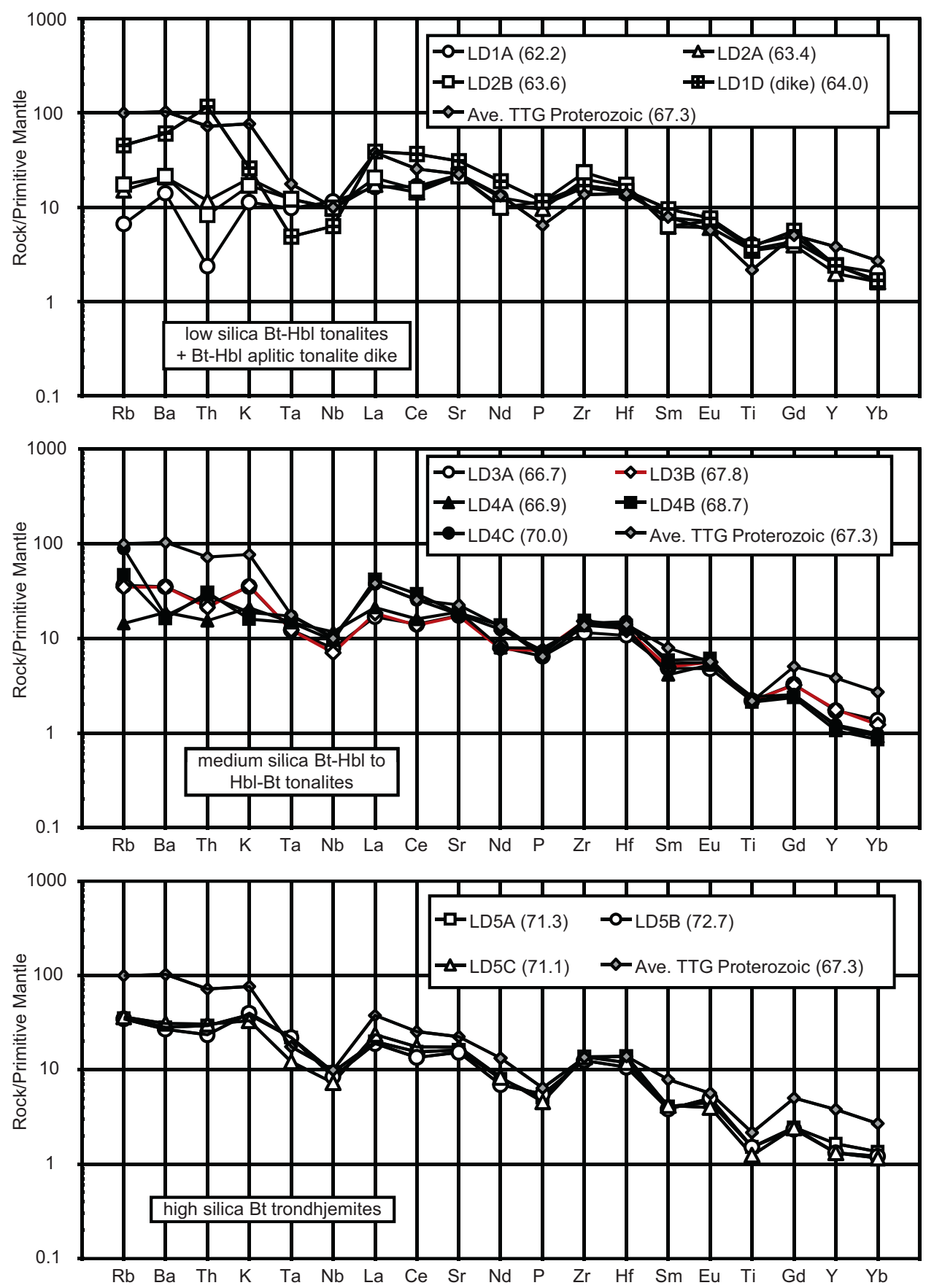

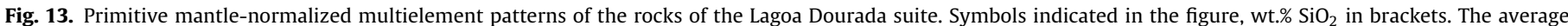
composition of Proterozoic TTG suites is shown for comparison (Ave. TTG Prot., data from Condie, 2005). Primitive mantle values after Sun and McDonough (1989).

as well as thorium) and light REE, and consequently shows strong positive spikes of strontium relative to the light REE (Fig. 13).

\section{Discussion}

In this section, the field, mineralogical, geochemical and isotopic data of the Lagoa Dourada suite are interpreted in the light of processes related to the origin and the magmatic evolution of the TTG suites. A summary of the petrological characteristics of the Lagoa Dourada suite and a comparison with the average composition of Proterozoic TTG suites are given in Table 6.

\subsection{Source rock}

The tonalitic and trondhjemitic rocks of the Lagoa Dourada suite have high Ca contents and low LILE (e.g. K, Rb, and Ba), light REE, Th and $U$ contents (Table 6 ). In addition, the suite has depleted $\mathrm{Nd}$ isotope compositions $\left(\varepsilon_{\mathrm{Nd}}(t)=+1.0\right.$ to +2.1 , Table 3$)$; lower than tholeiitic values of $\mathrm{Y}$ and $\mathrm{Yb}$ (Fig. 13); positive Eu/Eu* and $\mathrm{Sr} / \mathrm{Sr}^{*}$ anomalies on chondrite-normalized and primitive mantlenormalized diagrams (Figs. 11 and 13); and low $\mathrm{Mg \# ,} \mathrm{Cr}$ and $\mathrm{Ni}$ contents ( $<20 \mathrm{ppm})$.The low Mg\# of the Lagoa Dourada suite rocks, when compared at a similar silica content with the Mg\# of the other TTG suites (Smithies, 2000; Smithies et al., 2003; Condie, 2005; 


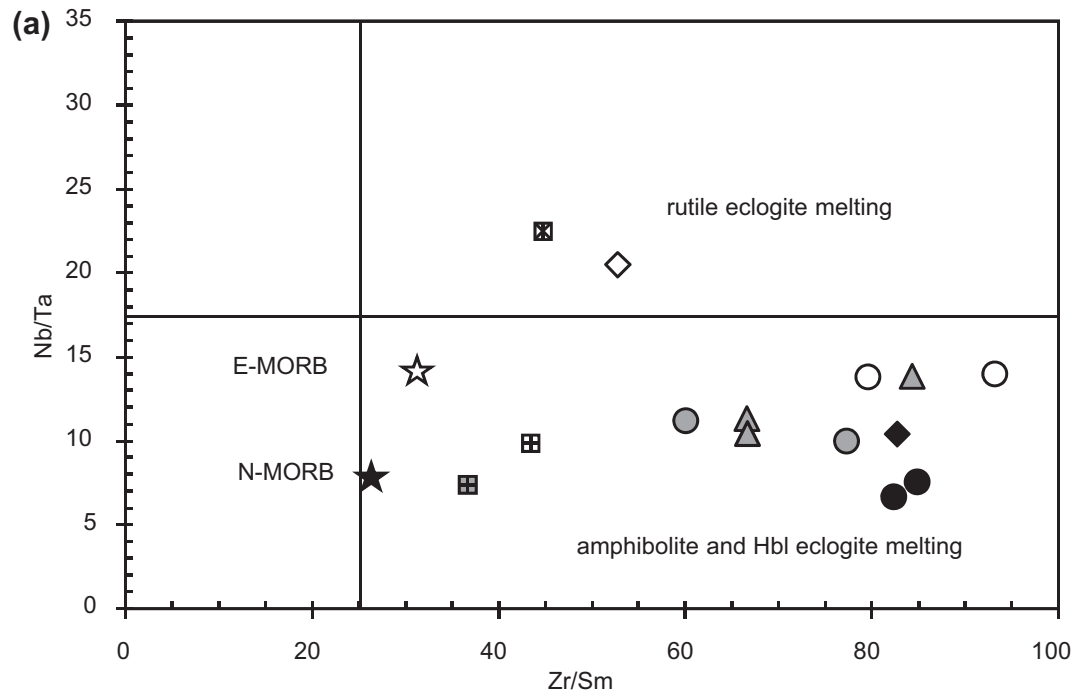

(b)

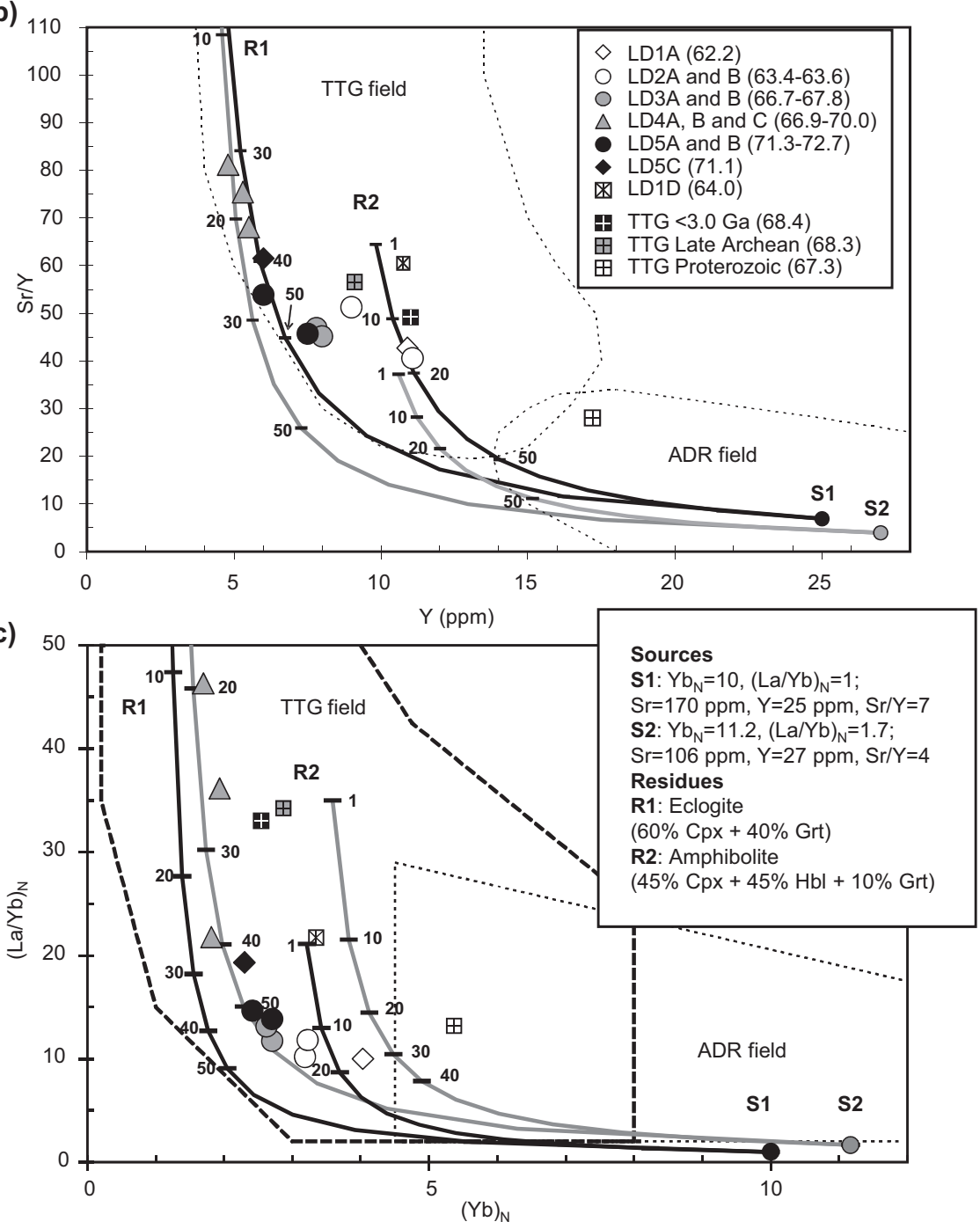

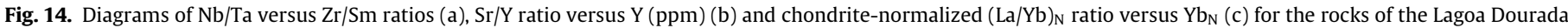

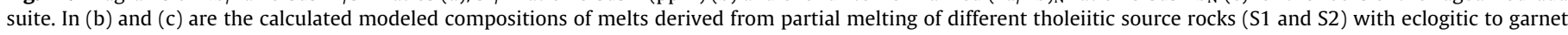

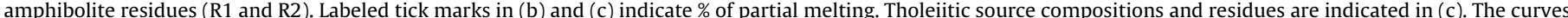

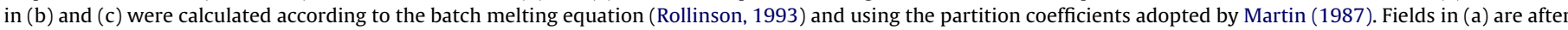

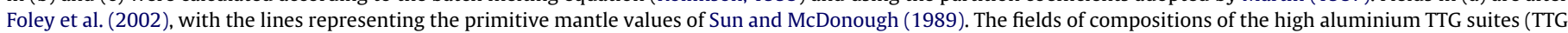

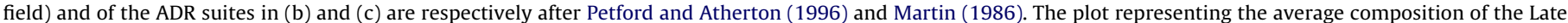

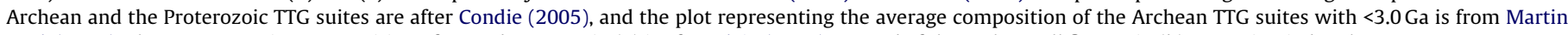
et al. (2005). The representative composition of $\mathrm{N}$ - and $\mathrm{E}-\mathrm{MORB}$ in (a) is after Klein (2004). Legend of the rocks to all figures in (b), wt.\% $\mathrm{SiO}_{2}$ in brackets. 

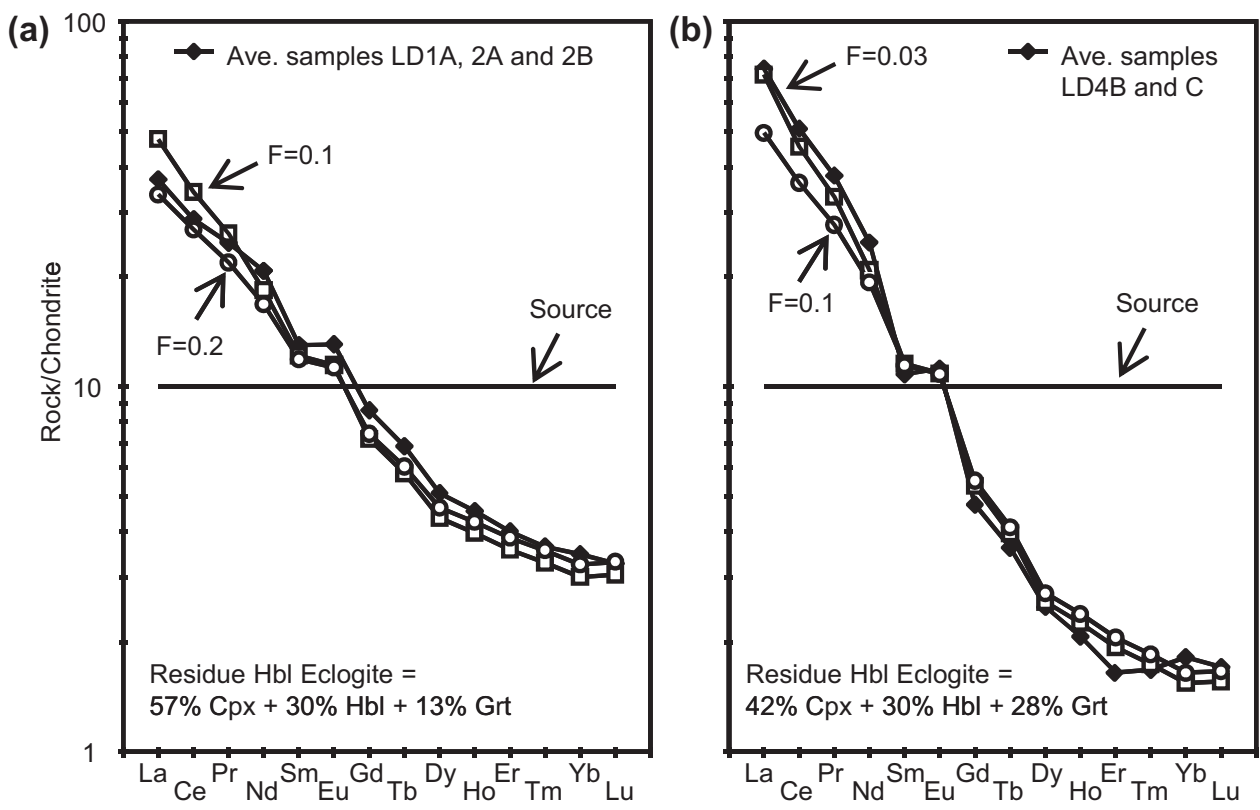

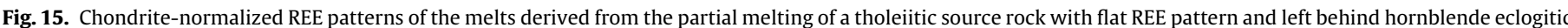

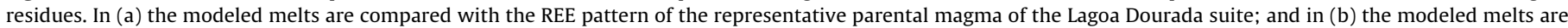

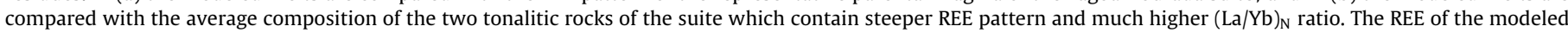
melts were calculated according to the batch melting equation (Rollinson, 1993) and adopting the same partition coefficients as Martin (1987). F indicates \% of melt.

Martin et al., 2005; Clemens et al., 2006; Stevenson et al., 2009; Moyen et al., 2010), indicates that the above mentioned depletion in incompatible trace elements is not an artifact of the degree of fractionation, but a genetic attribute that might be related to the geochemistry of the source rock and the depth of melting (Moyen et al., 2010). The absence of associated gabbro/diorite with the Lagoa Dourada suite rules out derivation from differentiation of a mafic melt (Arth et al., 1978). Therefore the most probable source
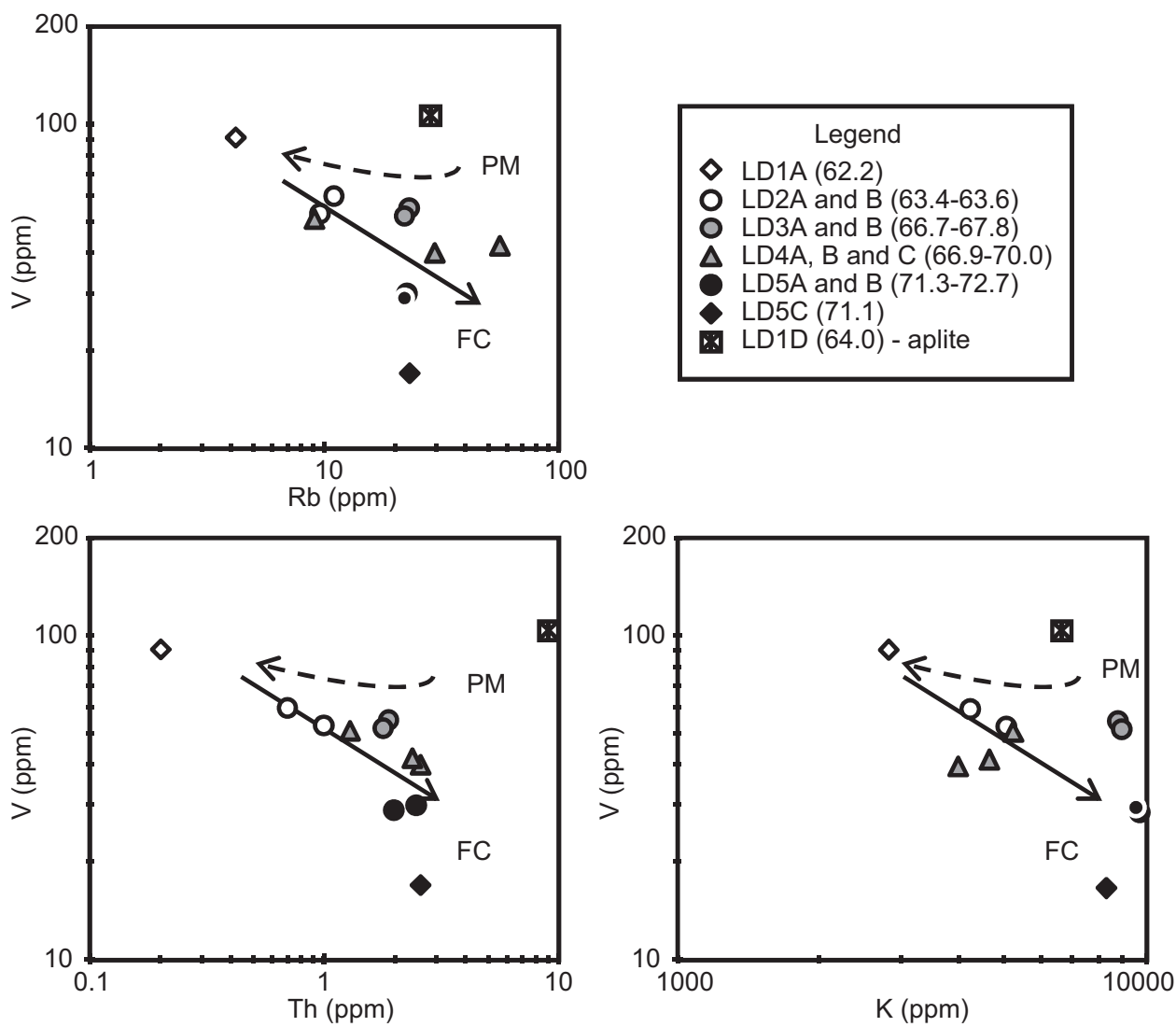

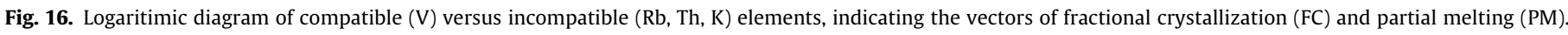
Based on Martin (1987). wt.\% $\mathrm{SiO}_{2}$ in brackets. 

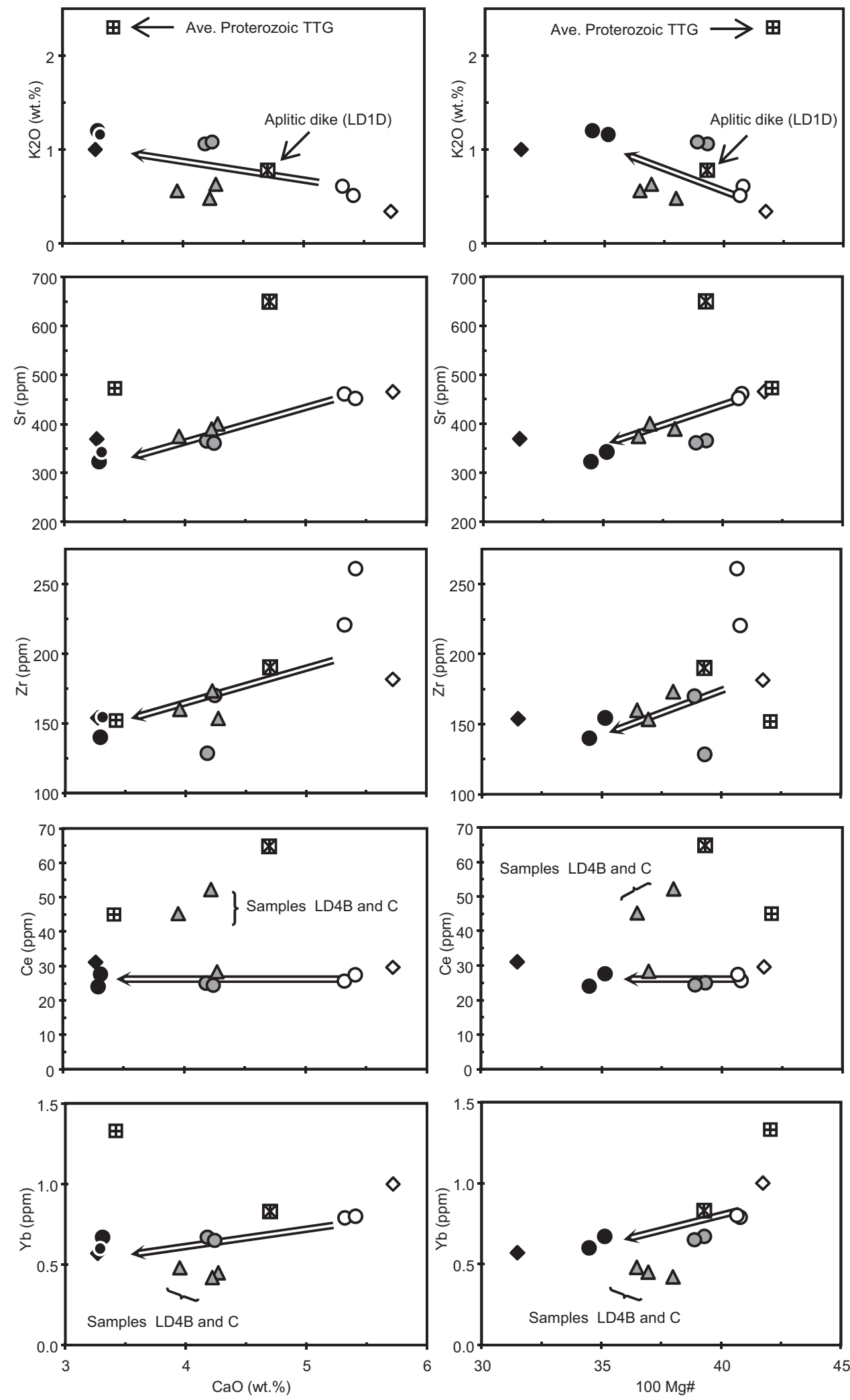

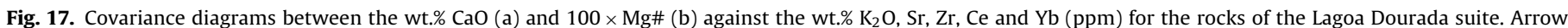

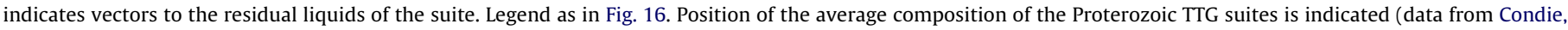
2005, 67.3 wt.\% $\mathrm{SiO}_{2}$ ).

rock for the suite is the melting of a mafic source (Martin, 1986; Martin, 1987; Rapp and Watson, 1995; Willie et al., 1997; Martin et al., 2005; Martin et al., 2005 and references therein, Clemens et al., 2006).
The depleted Nd isotope compositions of the Lagoa Dourada TTG suite suggest that the suite was derived from the melting of a mafic crust that had not long been separated from the mantle. Correlations of HFS element ratios, such as $\mathrm{Nb} / \mathrm{Ta}$ versus $\mathrm{Zr} / \mathrm{Sm}$ (Fig. 14a), in 
the suite are consistent with the melting of a tholeiitic source that left behind residual garnet amphibolite and/or hornblende eclogite (Foley et al., 2002). The absence of plagioclase in the residue is indicated by the relatively high $\mathrm{Sr}$ and low Y contents of the suite and by the $\mathrm{Sr} / \mathrm{Y}$ versus $\mathrm{Y}$ graph of Fig. 14b. In this diagram, samples of the Lagoa Dourada suite follow the modeled compositions of liquids derived from tholeiitic sources with eclogitic to garnet-clinopyroxene amphibolite residues containing no plagioclase. It is important to note that only the high-Sr tholeiitic source ( $\mathrm{S} 1$ source, with $\mathrm{Sr}=170 \mathrm{ppm}$ ) can account for the samples with lower $\mathrm{Sr} / \mathrm{Y}$ ratios and higher Y contents (Fig. 14b). Finally, on the $(\mathrm{La} / \mathrm{Yb})_{\mathrm{N}}$ versus $\mathrm{Yb}_{\mathrm{N}}$ graph (Fig. 14c), it is noteworthy that none of the samples of the Lagoa Dourada suite plots on the line of pure eclogite residue (R1) from a tholeiitic source with flat REE pattern (S1), nor on the line of garnet-clinopyroxene amphibolite residue (R2) to tholeiitic source with enriched light REE pattern (S2). The diagram suggests that the suite was derived from a light REE enriched tholeiitic source with eclogite residue, or a flat REE tholeiitic source with a mixed garnet-clinopyroxene amphibolite residue. The latter option is judged more realistic because of the high degree of partial melting required for the eclogite residue (>20\% to $30 \%$ for two samples of the LD4 station, and $>40 \%$ for all other samples). Thus, the most probable source rock for the Lagoa Dourada suite was a tholeiitic source with a flat REE pattern, $\sim 27 \mathrm{ppm} \mathrm{Y}$ and $\mathrm{Sr} / \mathrm{Y} \sim 7$ (e.g. $\mathrm{Sr} \sim 170 \mathrm{ppm}$ ). Melting took place relatively soon after the extraction of this mafic rock from the mantle and in the stability field of garnet-clinopyroxene amphibolite to hornblende eclogitic residues.

\subsection{Parental magma}

The most primitive rocks of the Lagoa Dourada suite are tonalites LD1A and LD2A and $\mathrm{B}$, with $62-64 \% \mathrm{SiO}_{2}$. These tonalites have the highest compatible element contents (i.e., $\mathrm{Ca}, \mathrm{Mg}, \mathrm{Fe}, \mathrm{Ti}, \mathrm{P}, \mathrm{V}, \mathrm{Sr}$, $\mathrm{Sc}, \mathrm{Zr}$ and middle to heavy REE) and the lowest incompatible element contents (i.e. K, Rb, Th and U, Figs. 9-12). For these reasons, the average composition of these three tonalites is assumed to be representative of the parental magma of the suite. This parental magma composition is much less siliceous than the average Archean and Proterozoic high-aluminium TTG suite (e.g. $\sim 68 \% \mathrm{SiO}_{2}$; Condie, 2005). However, tonalitic/dacitic compositions with $\sim 64 \% \mathrm{SiO}_{2}$ are also associated with the definition of the TTG suites (i.e., the high-aluminium tonalite-trondhjemite-dacite-TTD-series of Drummond and Defant, 1990; or the Phanerozoic Na-rich granitoids exemplified by Smithies, 2000). The REE pattern of the assumed parental magma of the Lagoa Dourada suite can be reproduced using a tholeiitic source with a flat REE pattern, moderate degrees of partial melting ( $10 \%$ to $20 \%$ ) and hornblende eclogitic residues with $57 \% \mathrm{Cpx}+30 \% \mathrm{Hbl}+13 \%$ Grt (Fig. 15a, modeled using batch melting equations of Rollinson, 1993). Modeling the tonalitic samples LD4 B and C, the only samples with higher $\mathrm{La} / \mathrm{Yb}_{\mathrm{N}}$ ratios (Figs. 11 and 12), and starting with the same tholeiitic composition, requires lower degrees of melting and residues richer in garnet instead of clinopyroxene ( $42 \% \mathrm{Cpx}+30 \% \mathrm{Hbl}+28 \% \mathrm{Grt}$, Fig. $15 \mathrm{~b})$.

\subsection{Magmatic differentiation}

The Lagoa Dourada tonalitic and trondhjemitic rocks range from $\sim 62$ to $\sim 73 \% \mathrm{SiO}_{2}$, showing tight inter-element correlation on the Harker diagrams between the low and the high silica members of the suite (Figs. 9 and 10). This suggests crystal fractionation as a possible mechanism to explain the magmatic differentiation of the suite (Kalsbeek, 2001; Huang et al., 2010). Fractional crystallization of hornblende, plagioclase, and accessory Fe-Ti oxides, zircon and apatite are indicated by the negative correlation of silica with $\mathrm{Al}, \mathrm{Ca}, \mathrm{Fe}, \mathrm{Mg}, \mathrm{Ti}$ and $\mathrm{P}$ as well as by trace elements such as $\mathrm{V}$,
$\mathrm{Sr}, \mathrm{Zr}$ and Y. Crystal fractionation is also indicated by plots of the different granitoid samples on logarithmic graphs of compatible (e.g. V) versus incompatible (e.g. Rb, Th or K) elements in the suite (Fig. 16).

Fig. 17 explores the possible role of fractional crystallization between different members of the suite through the construction of covariation diagrams of $\mathrm{K}_{2} \mathrm{O}, \mathrm{Sr}, \mathrm{Ce}, \mathrm{Y}$ and $\mathrm{Zr}$ as function of the $\mathrm{CaO}$ content and the $\mathrm{Mg \#}$. Because both the $\mathrm{CaO}$ content and the Mg\# are affected by hornblende and plagioclase, geochemical variations against these proxies can be used to examine the influence of plagioclase and amphibole fractionation on the tonalitic to trondhjemitic suites (Arth et al., 1978; Kalsbeek, 2001). The overall coherent behavior of the different suite members in these diagrams suggests that their compositions reproduce the hypothetical liquid line of descent of the suite starting from the proposed parental magma. The fractionating phases are the mineral assemblages observed in the investigated samples $(\mathrm{Pl}+\mathrm{Hbl}+\mathrm{Zrn}+\mathrm{Ap}+\mathrm{Fe}-\mathrm{Ti}$ minerals \pm Aln and Grt). Rocks (LD4B and C) with higher light REE and lower heavy REE contents $(\mathrm{Yb})$ cannot be modeled from the same parental magma as the other samples (Evans and Hanson, 1997), and are interpreted as representing different batches of magma produced from the same source under different melting conditions (Fig. 15). The presence of more than one melting event and intrusion of new batches of magma is supported by field observations in the form of the tonalitic aplite dikes (LD1D; Fig. 3b). Indeed, the geochemistry of the post-magmatic, pre- to syn-deformational tonalitic aplite dike (sample LD1D) has largely the same major element content as the intruded tonalitic samples at the same silica level (Fig. 9), but consistently higher trace element contents ( $\mathrm{Sr}, \mathrm{Ba}, \mathrm{Th}, \mathrm{U}$, and light REE; Figs. 10 and 11). This suggests that these magmatic dike phases are not derived from the same batches of magma as the tonalites. Nor do they represent the residual liquids of the main magma of the suite. Rather, they are most likely derived from different melt batches produced under different melting conditions.

\subsection{Geotectonic implications}

This study of the Lagoa Dourada suite demonstrates that construction of the Paleoproterozoic southern margin of the São Francisco craton included juvenile TTG plutonic crust that formed at ca. 2350 Ma. Geochemical and petrological parameters of the suite are consistent with its derivation from partial melting of MORBlike tholeiitic metabasaltic rocks with flat REE patterns. Moreover, the mantle-like $\varepsilon_{\mathrm{Nd}}(t)$ values of +1.0 to +2.1 indicate a short crustal residence time for the source protolith prior to melting. Thus, the emplacement of the suite is envisaged to represent the growth of new continental crust by partial melting of the depleted mantle to generate a MORB-type tholeiites, followed by the partial melting of these tholeiites to yield the parental magma of the suite. This model reproduces the two-stage petrogenesis of Archean TTG first proposed by Martin (1986). The depleted mantle model ages ( $\left.T_{\mathrm{DM}}\right)$ of the suite vary from $\sim 2.4$ to $2.5 \mathrm{Ga}$ and are only slightly older than the intrusion age (Table 4 ). These observations exclude lithologies such as the tholeiitic amphibolites or the quartz-dioritic and trondhjemitic gneisses from the northern edge of the Mineiro belt as possible source rocks and/or as possible crustal contaminants (Figs. 1, 2 and 7 and Table 4).

Major and trace element geochemistry and modeling, based on batch melting equations, suggest the melting region was situated in the hornblende eclogitic stability field, indicating a minimum of $\sim 30$ to $40 \mathrm{~km}$ depth and $700-800^{\circ} \mathrm{C}$ (Peacock et al., 1994; Rapp and Watson, 1995; Rapp, 1997; Foley et al., 2002; Clemens et al., 2006). A high pressure setting is also suggested by the accessory almandine garnet found in some members of the suite. The high $\mathrm{CaO}$ $(>4 \%)$ and low $\mathrm{MnO}(<3 \%)$ contents of the $\mathrm{Ca}-\mathrm{Mg}$-rich variety of the 
Table 4

$\mathrm{Nd}$ isotope composition of rocks of the Lagoa Dourada suite, and country rock metabasaltic amphibolite, quartz dioritic and trondhjemitic gneisses. ${ }^{\mathrm{a}}$

\begin{tabular}{|c|c|c|c|c|c|c|c|c|c|}
\hline Sample no. & Age (Ga) & $\mathrm{Sm}(\mathrm{ppm})^{\mathrm{b}}$ & $\mathrm{Nd}(\mathrm{ppm})^{\mathrm{b}}$ & ${ }^{147} \mathrm{Sm} /{ }^{144} \mathrm{Nd}^{\mathrm{b}}$ & ${ }^{143} \mathrm{Nd} /{ }^{144} \mathrm{Nd}^{\mathrm{c}}$ & $2 \sigma$ & $\varepsilon_{\mathrm{Nd}}(0)$ & $\varepsilon_{\mathrm{Nd}}(t)^{\mathrm{d}}$ & $T_{\mathrm{DM}}(\mathrm{Ga})^{\mathrm{e}}$ \\
\hline \multicolumn{10}{|l|}{ Lagoa Dourada suite } \\
\hline LD3A & 2.350 & 2.24 & 11.0 & 0.1233 & 0.511554 & 15 & -21.2 & +1.0 & 2.5 \\
\hline LD4B & 2.350 & 2.40 & 17.6 & 0.0821 & 0.510941 & 5 & -33.1 & +1.5 & 2.4 \\
\hline LD5B & 2.350 & 1.85 & 10.1 & 0.1111 & 0.511422 & 6 & -23.7 & +2.1 & 2.4 \\
\hline \multicolumn{10}{|c|}{ TH - metabasaltic country rock amphibolite } \\
\hline $\mathrm{TH}$ & $2.350^{\mathrm{f}}$ & 3.08 & 10.7 & 0.1750 & 0.512226 & 22 & -8.0 & $-1,5$ & \\
\hline \multicolumn{10}{|l|}{ Gneisses } \\
\hline Gn1 - trondjemitic & $2.350^{\mathrm{f}}$ & 2.75 & 28.9 & 0.0574 & 0.510104 & 9 & -49.4 & -7.4 & 2.9 \\
\hline Gn2 - qz dioritic & $2.350^{\mathrm{f}}$ & 8.38 & 55.2 & 0.0917 & 0.510473 & 10 & -42.2 & -10.6 & 3.2 \\
\hline Gn3 - qz dioritic & $2.350^{\mathrm{f}}$ & 4.38 & 21.9 & 0.1210 & 0.511068 & 9 & -30.6 & -7.8 & 3.3 \\
\hline
\end{tabular}

a $\mathrm{Sm}$ and $\mathrm{Nd}$ concentrations and ${ }^{147} \mathrm{Sm} /{ }^{144} \mathrm{Nd}$ ratios accurate to within $0.5 \%$.

b ${ }^{143} \mathrm{Nd} /{ }^{144} \mathrm{Nd}$ normalized to ${ }^{146} \mathrm{Nd} /{ }^{144} \mathrm{Nd}=0.7219$.

c $\varepsilon_{\mathrm{Nd}}(t)$ values from crystallization ages and chondritic ratios of ${ }^{143} \mathrm{Nd} /{ }^{144} \mathrm{Nd}=0.512638$ and ${ }^{147} \mathrm{Sm} /{ }^{144} \mathrm{Nd}=0.1966$. Maximum error is $0.5 \varepsilon_{\mathrm{Nd}}$ units.

d Nd model ages calculated using depleted mantle model of DePaolo (1981).

e Crystallization age unknown, the attributed ages are used to calculate $\varepsilon_{\mathrm{Nd}}(t)$ and to test possible crustal contaminat rocks for the granitoids of the Lagoa Dourada suite.

${ }^{f}$ For sample localities see Fig. 2. UTM coordinates for gneisses are 7730700N and 639650E (Gn1); 7718957N and 647974E (Gn2); 7704900N and 645903E (Gn3); for the TH amphibolite is $7710491 \mathrm{~N}$ and $637066 \mathrm{E}$; to the other samples see Table 5.

almandine garnets (Figs. 4 and 5; Table 2) are consistent with the compositions of igneous garnets (Harangi et al., 2001; Yuan et al., 2009). In addition, experimental and petrological studies indicate that these igneous garnets form in hydrous metaluminous andesitic to dacitic magmas at relatively high $\mathrm{P}(>7 \mathrm{kbar})$ and $\mathrm{T}\left(800-950{ }^{\circ} \mathrm{C}\right.$, Day et al., 1992; Alonso-Perez et al., 2009). These findings corroborate the high pressure setting of generation/crystallization of the Lagoa Dourada suite, as was deduced by the geochemistry and the trace element modeling.
Tectonic scenarios envisaged to account for the above mentioned isotopic, geochemical and mineralogical data of the Lagoa Dourada suite could include partial melting of subducted hot oceanic slab, melting of hydrous mafic rocks in arc systems or melting in the root zones of oceanic plateaus (see for example Martin et al., 2005; Condie, 2005 for discussion about tectonic settings to TTG suites). Slab melting produces magmas analogous to adakitic magmas (Drummond et al., 1996; Martin, 1999), however the Lagoa Dourada suite lacks any evidence of having equilibrated,

Table 5

Major and trace element data of rocks from the Lagoa Dourada suite. Oxides in wt.\%, trace elements in ppm.

\begin{tabular}{|c|c|c|c|c|c|c|c|c|c|c|c|c|c|c|c|c|c|c|c|c|c|c|c|c|}
\hline \multirow[t]{3}{*}{ Sample } & \multicolumn{24}{|c|}{ Locality } \\
\hline & \multirow{2}{*}{\multicolumn{2}{|c|}{$\begin{array}{l}\text { Northing } \\
\text { UTM }\end{array}$}} & \multicolumn{22}{|l|}{ Easting } \\
\hline & & & \multicolumn{2}{|l|}{ UTM } & \multirow[t]{2}{*}{$\mathrm{SiO}_{2}$} & \multirow{2}{*}{$\mathrm{TiO}_{2}$} & \multicolumn{2}{|c|}{$\mathrm{Al}_{2} \mathrm{O}_{3}$} & $\mathrm{Fe}_{2} \mathrm{O}_{3 \mathrm{t}}$ & $\mathrm{MnO}$ & $\mathrm{MgO}$ & $\mathrm{CaO}$ & \multirow[t]{2}{*}{$\mathrm{Na}_{2} \mathrm{O}$} & $\mathrm{K}_{2} \mathrm{O}$ & \multirow[t]{2}{*}{$\mathrm{P}_{2} \mathrm{O}_{5}$} & \multirow[t]{2}{*}{ LOI } & \multirow[t]{2}{*}{ Total } & \multirow[t]{2}{*}{$\mathrm{Ba}$} & \multirow[t]{2}{*}{$\mathrm{Rb}$} & $\mathrm{Sr}$ & \multirow[t]{2}{*}{$\mathrm{Y}$} & \multirow[t]{2}{*}{$\mathrm{Zr}$} & $\mathrm{Nb}$ & Th \\
\hline Lagoa & ourad & uite & & & & & & & & & & & & & & & & & & & & & & \\
\hline LD1A & 768 & 900 & 602500 & & 62.19 & 0.87 & 16.56 & & 6.22 & 0.08 & 2.25 & 5.72 & 4.85 & 0.34 & 0.23 & 0.50 & 99.81 & 98 & 4 & 466 & 11 & 182 & 8.2 & 0.2 \\
\hline LD2A & 765 & 279 & 604036 & & 63.40 & 0.75 & 16.54 & & 5.52 & 0.07 & 1.92 & 5.32 & 4.82 & 0.61 & 0.21 & 0.70 & 99.86 & 145 & 10 & 461 & 9 & 221 & 6.9 & 1.0 \\
\hline LD2B & 769 & 279 & 604036 & & 63.59 & 0.78 & 16.67 & & 5.55 & 0.06 & 1.92 & 5.41 & 4.67 & 0.51 & 0.25 & 0.67 & 100.08 & 148 & 11 & 452 & 11 & 261 & 7.0 & 0.7 \\
\hline LD3A & 765 & 325 & 598880 & & 66.70 & 0.47 & 16.62 & & 3.67 & 0.05 & 1.20 & 4.18 & 5.24 & 1.06 & 0.14 & 0.60 & 99.93 & 244 & 23 & 366 & 8 & 129 & 5.6 & 1.9 \\
\hline LD3B & 769 & 325 & 598880 & & 67.77 & 0.47 & 16.46 & & 3.58 & 0.05 & 1.15 & 4.24 & 5.07 & 1.08 & 0.16 & 0.50 & 100.53 & 243 & 22 & 361 & 8 & 170 & 5.0 & 1.8 \\
\hline LD4A & 768 & 582 & 598535 & & 66.86 & 0.52 & 16.25 & & 4.46 & 0.07 & 1.32 & 4.27 & 4.95 & 0.63 & 0.17 & 0.40 & 99.90 & 131 & 9 & 400 & 5 & 154 & 8.3 & 1.3 \\
\hline LD4B & 768 & 582 & 598535 & & 68.65 & 0.46 & 15.87 & & 3.75 & 0.05 & 1.16 & 4.22 & 4.76 & 0.48 & 0.15 & 0.40 & 99.95 & 113 & 30 & 390 & 5 & 173 & 6.8 & 2.6 \\
\hline LD4C & 768 & 582 & 598535 & & 69.99 & 0.47 & 15.00 & & 4.07 & 0.06 & 1.18 & 3.95 & 4.43 & 0.56 & 0.16 & 0.10 & 99.97 & 120 & 56 & 375 & 56 & 160 & 7.3 & 2.4 \\
\hline LD5A & 768 & 3562 & 591318 & & 71.29 & 0.33 & 14.91 & & 3.07 & 0.06 & 0.84 & 3.31 & 4.43 & 1.16 & 0.11 & 0.40 & 99.91 & 198 & 23 & 343 & 8 & 155 & 6.8 & 2.5 \\
\hline LD5B & 768 & 5562 & 591318 & & 72.66 & 0.33 & 14.60 & & 3.01 & 0.04 & 0.80 & 3.29 & 4.23 & 1.20 & 0.12 & 0.52 & 100.80 & 188 & 22 & 323 & 36 & 140 & 6.0 & 2.0 \\
\hline LD5C & 768 & 562 & 591318 & & 71.05 & 0.27 & 15.57 & & 2.67 & 0.05 & 0.62 & 3.27 & 4.90 & 1.00 & 0.10 & 0.40 & 99.90 & 217 & 23 & 369 & 6 & 154 & 5.2 & 2.6 \\
\hline LD1D & 768 & 900 & 602500 & & 64.00 & 0.83 & 16.95 & & 5.08 & 0.05 & 1.66 & 4.70 & 4.78 & 0.78 & 0.25 & 0.70 & 99.78 & 422 & 29 & 650 & 11 & 190 & 4.5 & 9.9 \\
\hline Sample & & & & & & & & & & & & & & & & & & & & & & & & \\
\hline & $\mathrm{Ni}$ & $\mathrm{Cr}$ & $\mathrm{V}$ & Sc & $\mathrm{Hf}$ & Ta & $\mathrm{U}$ & $\mathrm{La}$ & & $\mathrm{Ce}$ & $\mathrm{Pr}$ & $\mathrm{Nd}$ & $\mathrm{Sm}$ & $\mathrm{Eu}$ & Gd & $\mathrm{Tb}$ & Dy & Ho & $\mathrm{Er}$ & & $\mathrm{Tm}$ & $\mathrm{Yb}$ & & $\mathrm{Lu}$ \\
\hline LD1A & 28 & $<20$ & 91 & 9 & 4.3 & 0.4 & 0.3 & 14. & & 29.60 & 3.97 & 17.10 & 3.44 & 1.19 & 2.96 & 0.440 & 2.190 & 0.410 & $1.0 \mathrm{~S}$ & & 0.150 & 1.000 & & 0.140 \\
\hline LD2A & $<20$ & $<20$ & 53 & 8 & 5.1 & 0.5 & 0.3 & 11. & & 25.60 & 3.21 & 13.80 & 2.77 & 1.02 & 2.35 & 0.360 & 1.760 & 0.340 & 0.91 & & 0.130 & 0.790 & & 0.110 \\
\hline LD2B & $<20$ & $<20$ & 60 & 8 & 5.3 & 0.5 & 0.3 & 14. & & 27.40 & 3.87 & 13.40 & 2.80 & 1.20 & 2.60 & 0.350 & 1.900 & 0.350 & 1.00 & & 0.130 & 0.800 & & 0.125 \\
\hline LD3A & $<20$ & $<20$ & 55 & 5 & 3.3 & 0.5 & 0.6 & 11. & & 25.00 & 2.80 & 10.90 & 2.14 & 0.80 & 1.93 & 0.290 & 1.500 & 0.270 & 0.70 & & 0.100 & 0.670 & & 0.100 \\
\hline LD3B & $<20$ & $<20$ & 52 & 5 & 3.8 & 0.5 & 0.5 & 12. & & 24.40 & 3.07 & 10.40 & 2.20 & 0.94 & 1.90 & 0.300 & 1.500 & 0.300 & 0.80 & & 0.110 & 0.650 & & 0.105 \\
\hline LD4A & $<20$ & $<20$ & 51 & 4 & 3.9 & 0.6 & 0.7 & 14. & & 28.30 & 2.99 & 10.70 & 1.82 & 0.88 & 1.51 & 0.210 & 1.000 & 0.190 & $0.4 \mathrm{~S}$ & & 0.070 & 0.450 & & 0.070 \\
\hline LD4B & $<20$ & $<20$ & 40 & 4 & 4.2 & 0.6 & 0.4 & 28. & & 52.20 & 5.25 & 18.60 & 2.60 & 1.02 & 1.41 & 0.190 & 0.870 & 0.160 & 0.38 & & 0.060 & 0.420 & & 0.050 \\
\hline LD4C & $<20$ & $<20$ & 42 & 4 & 4.6 & 0.7 & 0.5 & 25. & & 45.20 & 4.62 & 16.70 & 2.40 & 0.93 & 1.50 & 0.200 & 1.030 & 0.170 & 0.44 & & 0.060 & 0.480 & & 0.080 \\
\hline LD5A & $<20$ & $<20$ & 30 & 3 & 4.3 & 0.9 & 1.1 & 13. & & 27.60 & 2.97 & 10.90 & 1.82 & 0.76 & 1.47 & 0.240 & 1.170 & 0.240 & 0.67 & & 0.100 & 0.670 & & 0.110 \\
\hline LD5B & $<20$ & $<20$ & 29 & 3 & 3.3 & 0.9 & 0.8 & 13. & & 24.00 & 2.98 & 9.40 & 1.70 & 0.84 & 1.40 & 0.200 & 1.200 & 0.230 & 0.60 & & 0.090 & 0.600 & & 0.090 \\
\hline LD5C & $<20$ & $<20$ & 17 & 2 & 3.7 & 0.5 & 0.7 & 16. & & 31.10 & 3.23 & 11.30 & 1.86 & 0.67 & 1.44 & 0.220 & 1.060 & 0.200 & 0.56 & & 0.080 & 0.570 & & 0.080 \\
\hline LD1D & $<20$ & $<20$ & 113 & 7 & 4.6 & 0.2 & 0.8 & 26. & & 64.80 & 6.33 & 25.40 & 4.25 & 1.28 & 3.34 & 0.430 & 2.050 & 0.350 & $0.8 \mathrm{~s}$ & & 0.130 & 0.830 & & 0.120 \\
\hline
\end{tabular}

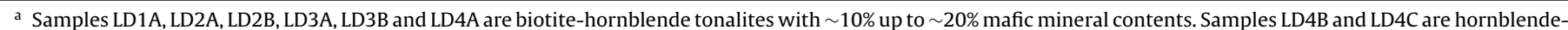

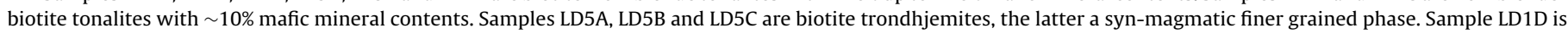
a highly foliated biotite-hornblende aplitic tonalite dike from the LD1 station. 


\section{Table 6}

Petrogenetic parameters for the Lagoa Dourada suite. ${ }^{\mathrm{a}}$

\begin{tabular}{|c|c|}
\hline Age $\mathrm{U}-\mathrm{Pb}$ & 2350-Ма \\
\hline Nd isotopes & Juvenile, depleted source, $\varepsilon_{\mathrm{Nd}}(t)>0$ \\
\hline Rock types & Hbl-Bt To to Bt-Tdj \\
\hline $\mathrm{Ab}-\mathrm{An}-$ Or classif. ${ }^{\mathrm{b}}$ & To-Tdj normative \\
\hline Acc. Minerals & Zrn, Ap, Mgt, Ttn, Grt \pm Aln \\
\hline \multicolumn{2}{|l|}{ Major elements } \\
\hline Silica content & $\begin{array}{l}\text { Intermediate to acid } \\
(62-73 \text { wt.\%) }\end{array}$ \\
\hline $\mathrm{A} / \mathrm{CNK}$ index & $\begin{array}{l}\text { Metaluminous to slightly peraluminous; } \\
0.88 \leq \mathrm{A} / \mathrm{CNK} \leq 1.03\end{array}$ \\
\hline $\mathrm{Al}_{2} \mathrm{O}_{3}$ classif. $^{\mathrm{b}}$ & High $\mathrm{Al}, \geq 14.6$ wt. $\% \mathrm{Al}_{2} \mathrm{O}_{3}$, \\
\hline $\mathrm{K}_{2} \mathrm{O}$ vs. $\mathrm{SiO}_{2}{ }^{\mathrm{c}}$ & Low-K series \\
\hline $\mathrm{K}_{2} \mathrm{O} / \mathrm{Na}_{2} \mathrm{O}$ & Very low, $\leq 0.3$ \\
\hline $\mathrm{Na}_{2} \mathrm{O}$ (wt.\%) & High, $\geq 4.2 \%$; trondhjemitic members \\
\hline CaO-classif. ${ }^{b}$ & $\begin{array}{l}\text { High-Ca, } \geq 3.3 \text { wt.\%, with oligoclase and } \\
\text { Ca-Mg almandine garnet }\end{array}$ \\
\hline Mg-classif. ${ }^{\mathrm{d}}$ & Low-Mg, $\leq 1.9$ wt.\% MgO, $0.34 \leq \mathrm{Mg} \# \leq 0.42$ \\
\hline \multicolumn{2}{|l|}{ Trace elements } \\
\hline $\mathrm{Cr}(\mathrm{ppm})$ & Low, $<20$ \\
\hline $\operatorname{LILE}(\mathrm{ppm})$ & $\begin{array}{l}\text { Low } \mathrm{Rb}(\leq 56) \text {, low } \mathrm{Ba}(\leq 244) \text { and moderate to } \\
\text { slightly high } \mathrm{Sr}(466-323)\end{array}$ \\
\hline $\mathrm{Rb} / \mathrm{Sr}$ & $\begin{array}{l}\text { Low, } \leq 0.15 \text {; most of values between } 0.02 \text { and } \\
0.08\end{array}$ \\
\hline $\mathrm{K} / \mathrm{Rb}$ & Moderate to high, $83-670 ;$ most of values $\geq 360$ \\
\hline $\mathrm{Sr} / \mathrm{Ba}$ & High, $\geq 1.5$ up to 4.8 \\
\hline REE total (ppm) & Low, 56-112; most of values $<80$ \\
\hline HREE - Yb (ppm) & Low, $\leq 1.00$ \\
\hline$(\mathrm{La} / \mathrm{Yb})_{\mathrm{N}}$ & $\begin{array}{l}\text { Moderate to high, } \geq 10 \text { to } 46 \text {; most of values } \\
\text { between } 10 \text { and } 22\end{array}$ \\
\hline$(\mathrm{La} / \mathrm{Sm})_{\mathrm{N}}$ & $\begin{array}{l}\text { Moderate to high, } 2.7-7.0 \text {; most of values } \\
\text { between } 2.7 \text { and } 5.5\end{array}$ \\
\hline$(\mathrm{Gd} / \mathrm{Yb})_{\mathrm{N}}$ & Moderate to high, 1.8-3.0; \\
\hline Eu/Eu* anomalies & Positive anomalies, $\geq 1.1$ to 1.6 \\
\hline HFSE (ppm) & $\begin{array}{l}\text { Very low } \mathrm{Th}(0.7-2.6) \text {, moderate } \mathrm{Nb}(5-8) \text {, } \\
\text { moderate to high } \mathrm{Zr}(\geq 128 \text { to } 261) \text {, low } \mathrm{Y} \\
(5-11)\end{array}$ \\
\hline \multicolumn{2}{|l|}{ LILE/HFSE } \\
\hline $\mathrm{Ba} / \mathrm{La}$ & Low (3.9-21) \\
\hline Th/La & Low $(0.01-0.18)$ \\
\hline $\mathrm{Sr} / \mathrm{Nd}$ & Moderate (21-37) \\
\hline $\mathrm{La} / \mathrm{Sm}$ & Moderate (4.3-11.1) \\
\hline $\mathrm{Sr} / \mathrm{Y}$ & $\begin{array}{l}\text { Moderate to high (41-81), most of values } \\
\text { between } 41 \text { and } 54\end{array}$ \\
\hline
\end{tabular}

a Only the granitoid rocks of the suite were used for this classification. The post-magmatic low silica tonalitic aplite dike (sample LD1D) was not used. Unless indicated, the classification is based on comparison with the average composition (and standard deviation) of Proterozoic high-Al TTG suite ( $67.3 \mathrm{wt} . \% \mathrm{SiO}_{2}$, Condie, 2005). Moderate, low or high refers, respectively to lower or higher contents than this reference frame.

b Classification according Barker (1979), $\mathrm{Al}_{2} \mathrm{O}_{3} \geq 15$ wt.\% to $70 \%$ wt.\% $\mathrm{SiO}_{2}$. To: tonalite; Grd: granodiorite; Tdj: trondhjemite.

c Classification according Le Maitre (1989).

d Classification as "low" Mg types is based on the arbitrary limit Mg\#=0.5.

or reacted with the mantle wedge, (e.g., $\mathrm{Mg \#}>47$ and high- $\mathrm{Cr}$ and -Ni; Smithies, 2000). The flat REE tholeiitic source of the Lagoa Dourada suite, as inferred from geochemical modeling, is more consistent with melting within a non-enriched environment such as a juvenile subduction environment, flat subduction, or an oceanic plateau (Smithies et al., 2003). The Lagoa Dourada suite is broadly associated with major tracts of the ca. 2.2-2.1 Ga Paleoproterozoic Trans-Amazonian plutonic suites of the Mineiro belt (Figs. 1 and 2), all of which intrude a series of NE-SW greenstone belts within the southwestern Quadrilátero Ferrífero region (Teixeira et al., 2000; Campos and Carneiro, 2008; Ávila et al., 2010). There are no precise geochronological data for these greenstone belts. They may be Neoarchean like the $\sim 2.77$ Ga Rio das Velhas Supergroup greenstone belt north of the Engenho fault (Fig. 1), but could also be Paleoproterozoic oceanic counterparts to the platformal Minas Supergroup (Toledo, 2002; Campos and Carneiro, 2008; Ávila et al., 2010). Further studies of the granitoids and greenstone belts are required to determine if melting of these greenstone belt sequences led to the generation of the Lagoa Dourada suite. The Lagoa Dourada suite represents a small ( $\left.50-80 \mathrm{~km}^{2}\right)$, but unequivocal example of juvenile crust produced within a period known for a lack of crust formation (Condie et al., 2009a,b; Condie and Aster, 2010). This finding reinforces a growing body of evidence (Vasquez et al., 2008; Santos et al., 2009) indicating that, although rare on a global scale, ca. 2.35-2.30 Ga juvenile granitoids are an important component of the Proterozoic evolution of the Sao Francisco craton in Brazil.

\section{Conclusions}

This study establishes a new episode of crustal growth (ca. $2350 \mathrm{Ma}$ ) for the southern margin of the São Francisco craton, southeastern Brazil. This episode is represented by the Lagoa Dourada high-aluminium TTG suite. The mineralogical, geochemical, $\mathrm{Nd}$ isotopes and $\mathrm{U}-\mathrm{Pb}$ geochronological data indicate the granitoids were likely derived from tholeiitic source rocks melted at the hornblende eclogitic stability field soon after they were extracted from the mantle. Fractional crystallization is suggested as the main mechanism controlling the magmatic differentiation of the suite, along with concomitant episodic emplacement of different batches of magma that represent different parameters of melting of the source. Accessory $\mathrm{Ca}-\mathrm{Mg}$ almandine garnet of probable igneous origin indicates the magmas crystallized at relatively high pressure and temperature. The petrogenesis of this suite seems to be related to the partial melting of the roots of tholeiitic greenstone belt packages in an intra-oceanic tectonic setting. The Lagoa Dourada suite is a rare example of ca. $2350 \mathrm{Ma}$ juvenile crust formation linking two major periods of prolonged orogenic granitoid magmatism during the Precambrian in Brazil; the Neoarchean, characterized by the large terrains dominated by TTG batholiths and derivative gneissic complexes, and the Paleoproterozoic 2.2-2.1 Ga production of TTG and granitic calc-alkaline suites.

\section{Acknowledgements}

The first author thanks the GEOTOP for providing technical and analytical support. L. A.R. Seixas received a CAPES/Brasília-Brazil fellowship (process 0918-08-0). Field work during the 2008 academic year was sponsored by Universidade Federal de Ouro Preto, Ouro Preto, Brazil (UFOP). Microprobe analyses were funded by a FAPEMIG (Minas Gerais, Brazil) grant to L. Seixas (CRA 440/2002). RS was supported by a NSERC Discovery Grant. The comments and criticism of the two anonymous reviewers are gratefully appreciated.

\section{References}

Alkmim, F.F., Marshak, S., 1998. Transamazonian orogeny in the southern São Francisco craton region, Minas Gerais, Brazil: evidence for Paleoproterozoic collision and collapse in the Quadrilátero Ferrífero. Precamb. Res. 90, 29-58.

Almeida, F.F.M., Neves, B.B.B., Carneiro, C.D.R., 2000. The origin and evolution of the South American platform. Earth Sci. Rev. 50, 77-111.

Alonso-Perez, R., Müntener, O., Ulmer, P., 2009. Igneous garnet and amphibole fractionation in the roots of island arcs: experimental constraints on andesitic liquids. Contrib. Mineral. Petrol. 157, 541-558.

Arth, J.G., Barker, F., Peterman, Z.E., Frideman, I., 1978. Geochemistry of the gabbrodiorite-tonalite-trondhjemite suite of southwest Finland and its implications for the origin of tonalitic and trondhjemitic magmas. J. Petrol. 19, 289-316.

Ávila, C.A., Teixeira, W., Cordani, U.G., Moura, C.A.V., Pereira, R.M., 2010. Rhyacian $(2.23-2.20 \mathrm{Ga})$ juvenile accretion in the southern São Francisco craton, Brazil: geochemical and isotopic evidence from the Serrinha magmatic suite, Mineiro belt. J. S. Am. Earth Sci. 29, 464-482.

Baltazar, O.F., Zuchetti, M., 2007. Lithofacies Associations and structural evolution of the Archean Rio das Velhas greenstone belt, Quadrilátero Ferrífero, Brazil: a review of a setting of gold deposits. Ore Geol. Rev. 32, 471-499. 
Barker, F., 1979. Trondhjemite: definition, environment and hypotheses of origin. In: Barker, F. (Ed.), Trondhjemites, Dacites and Related Rocks. Elsevier, New York, pp. 1-12.

Barker, F., Arth, J.G., 1976. Generation of trondhjemitic-tonalitic liquids and Archaean bimodal trondhjemite-basalt suites. Geology 4, 596-600.

Barnes, C.G., Petersen, S.W., Kistler, R.W., Murray, R., Kays, M.A., 1996. Source and tectonic implications of tonalite-trondhjemite magmatism in the Klamath Mountains. Contrib. Miner. Petrol. 123, 40-60.

Campos, J.C.S., Carneiro, M.A., 2008. Neoarchean and Paleoproterozoic granitoids marginal to the Jeceaba-Bom Sucesso lineament (SE border of the southern São Francisco craton): genesis and tectonic evolution. J. S. Am. Earth Sci. 26, 463-484.

Clemens, J.D., Yearron, L.M., Stevens, G., 2006. Barberton (South Africa) TTG magmas: geochemical and experimental constraints on source-rock petrology, pressure of formation and tectonic setting. Precamb. Res. 151, 53-78.

Condie, K.C., 2005. TTGs and adakites: are they both slab melts? Lithos 80, 33-44.

Condie, K.C., Aster, C.R., 2010. Episodic zircon age spectra of orogenic granitoids the supercontinent connection and continental growth. Precamb. Res. 180 227-236.

Condie, K.C., Belousova, E., Griffin, W.L., Sircombe, K.N., 2009a. Granitoid events in space and time: constraints from igneous and detrital zircon age spectra. Gondwana Res. 15, 228-242.

Condie, K.C., O'Neill, C., Aster, C.R., 2009b. Evidence and implications for a widespread magmatic shutdown for $250 \mathrm{My}$ on Earth. Earth Planet. Sci. Lett 282, 294-298.

Cordani, U.G., Sato, K., 1999. Crustal evolution of the South American Platform, based on $\mathrm{Nd}$ isotopic systematics on granitoid rocks. Episodes 22, 167-173.

Dahlquist, J.A., Galindo, C., Pankhurst, R.J., Rapela, C.W., Alasino, P.H., Saavedra, J., Fanning, C.M., 2007. Magmatic evolution of the Peñón Rosado granite: petrogenesis of garnet-bearing granitoids. Lithos 95, 177-207.

Day, R.A., Green, T.H., Smith, I.E.M., 1992. The origin and significance of garnet phenocrysts and garnet-bearing xenoliths in Miocene calk-alkaline volcanics from Northland. N. Z. J. Petrol. 33, 125-161.

DePaolo, D.J., 1981. Neodymium isotopes in the Colorado Front Range and crust-mantle evolution in the Proterozoic. Nature 291, 193-196.

Dorr II, J.V.N., 1969. Physiographic, stratigraphic and structural development of the Quadrilátero Ferrífero, Minas Gerais, Brazil. U.S. Geol. Surv. Prof. Paper 641-A, pp. $1-110$.

Droop, G.T.R., 1987. A general equation for estimating $\mathrm{Fe}^{3+}$ concentrations in ferromagnesian silicates and oxides from microprobe analyses using stoichiometric criteria. Mineral. Mag. 51, 431-435.

Drummond, M.S., Defant, M.J., 1990. A model for trondhjemite-tonalite-dacite genesis and crustal growth via slab melting: Archean to modern comparisons. J. Geophys. Res. 95, 21503-21521.

Drummond, M.S., Defant, M.J., Kepezhinskas, P.K., 1996. Petrogenesis of slab-derived trondhjemite-tonalite-dacite/adakite magmas. Trans. R. Soc. Edinburgh Earth Sci. 87, 205-215.

Evans, O.C., Hanson, G.N., 1997. Late- to post-kinematic Archaean granitoids of the S.W. Superior province: derivation through direct mantle melting. In: De Wit, M.J., Ashwal, L.D. (Eds.), Greenstone Belts. Clarendon Press, Oxford, pp. 280-295.

Foley, S.F., Tiepolo, M., Vannucci, R., 2002. Growth of early continental crust controlled by melting of amphibolite in subduction zones. Nature 417, 837-840.

Harangi, S.Z., Downes, H., Kosá, L., Szabó, C.S., Thirlwall, M.F., Mason, P.R.D., Mattey, D., 2001. Almandine garnet in calc-alkaline volcanic rocks of the Northern Pannonian Basin (Eastern-Central Europe): geochemistry, petrogenesis and geodynamic implications. J. Petrol. 42, 1813-1843.

Hartmann, L.A., Delgado, I.M., 2001. Cratons and orogenic belts of the Brazilian Shield and their contained gold deposits. Min. Dep. 36, 207-217.

Hartmann, L.A., Endo, I., Suita, M.T.F., Santos, J.O.S., Frantz, J.C., Carneiro, M.A., McNaughton, N.J., Barley, M.E., 2006. Provenance and age delimitation of Quadrilátero Ferrífero sandstones based on zircon $\mathrm{U}-\mathrm{Pb}$ isotopes. J. S. Am. Earth Sci. 20, 273-285.

Heineck, C.A., Silva, L.C., Leite, C.A., Vieira, V.S., Silva, M.A., Baars, F.J., Perrotta, M., Salvador, E.D., Lopes, R.C., Silva, M.G.M., Valente, C.R., Lacerda Filho, J.V., Drummond, J.B.V., 2003. Mapa Geológico de Minas Gerais, Escala 1:1,000,000. COMIG, Belo Horizonte, CD ROM.

Huang, X.-L., Niu, Y., Xu, Y.-G., Yang, Q.-J., Zhong, J.-W., 2010. Geochemistry of TTG and TTG-like gneisses from Lushan-Taihua complex in the southern North China Craton: Implications for late Archean crustal accretion. Precamb. Res. 182, 43-56.

Kalsbeek, F., 2001. Geochemical comparison between Archaean and Proterozoic orthogneisses from the Nagssugtoqidian orogen, West Greenland. Precamb. Res. $105,165-181$.

Klein, E.M., 2004. Geochemistry of the igneous oceanic crust. In: Rudnick, R.L. (Ed.), Treatise on Geochemistry, The Crust. Elsevier, San Diego, pp. 433-463.

Le Maitre, R.W., 1989. A Classification of Igneous Rocks and Glossary of Terms Blackwell, Oxford.

Machado, N., Carneiro, M.A., 1992. U-Pb evidence of late Archean tectono-thermal activity in the southern São Francisco shield, Brazil. Can. J. Earth Sci. 29 2341-2346.

Machado, N., Noce, C.M., Ladeira, E.A., Oliveira, B.O., 1992. U-Pb geochronology of Archean magmatism and Proterozoic metamorphism in the Quadrilátero Ferrífero, southern São Francisco craton, Brazil. Geol. Soc. Am. Bull. 104, $122-1227$.

Machado, N., Schrank, A., Noce, C.M., Gauthier, G., 1996. Ages of detrital zircon from Archean-Paleoproterozoic sequences: implications for Greenstone Belt setting and evolution of Transamazonian foreland basin in Quadrilátero Ferrífero, southeast Brazil. Earth Planet. Sci. Lett. 141, 259-276.

Martin, H., 1986. Effect of steeper Archean geothermal gradient on geochemistry of subduction-zone magma. Geology 14, 753-756.

Martin, H., 1987. Petrogenesis of Archean trondhjemites, tonalites and granodiorites from eastern Finland: major and trace element geochemistry. J. Petrol. 28 921-953.

Martin, H., 1999. Adakitic magmas: modern analogues of Archaean granitoids. Lithos 46, 411-429.

Martin, H., Smithies, R.H., Rapp, R., Moyen, J.F., Champion, D., 2005. An overview of adakite, tonalite-trondhjemite-granodiorite (TTG), and sanukitoid: relationships and some implications for crustal evolution. Lithos 79, 1-24.

Moyen, J.-F., Champion, D., Smithies, R.H., 2010. The geochemistry of Archaean plagioclase-rich granites as a marker of source enrichment and depth of melting. Trans. R. Soc. Edinburgh Earth Sci. 100, 35-50.

Noce, C.M., 1995. Geocronologia dos Eventos Magmáticos, Sedimentares e Metamórficos na Região do Quadrilátero Ferrífero, Minas Gerais. Unpublished PhD Thesis. Universidade de São Paulo. São Paulo, Brazil, 128 p.

Noce, C.M., Pedrosa-Soares, A.C., Silva, L.C., Armstrong, R., Piuzana, D., 2007a. Evolution of polycyclic basement complexes in the Araçuaí Orogen based on $\mathrm{U}-\mathrm{Pb}$ SHRIMP data: implications for Brazil-Africa links in Paleoproterozoic time. Precamb. Res. 159, 60-78.

Noce, C.M., Tassinari, C.G., Lobato, L.M., 2007b. Geochronological framework of the Quadrilátero Ferrífero, with emphasis on the age of gold mineralization hosted in Archean greenstone belts. Ore Geol. Rev. 32, 500-510.

Noce, C.M., Teixeira, W., Queménéur, J.J.G., Martins, V.T.S., Bolzaquini, E., 2000. Isotopic signatures of Paleoproterozoic granitoids from the southern São Francisco Craton and implications for the evolution of the Transamazonian Orogeny. J. S. Am. Earth Sci. 13, 225-239.

Noce, C.M., Zucchetti, M., Baltazar, O.F., Armstrong, R., Dantas, E.L., Renger, F.E., Lobato, L.M., 2005. Age of felsic volcanism and the role of ancient continental crust in the evolution of the Neoarchean Rio das Velhas greenstone belt (Quadrilátero Ferrífero, Brazil): U-Pb zircon dating of volcaniclastic graywackes. Precamb. Res. 141, 67-82.

O'Connor, J.T., 1965. A classification for quartz-rich igneous rocks based on feldspar ratios. U.S. Geol. Surv. Prof. Paper 525-B, pp. 79-84

Peacock, S.M., Rushmer, T., Thompson, A.B., 1994. Partial melting of subducting oceanic crust. Earth Planet. Sci. Lett. 121, 227-244.

Petford, N., Atherton, M., 1996. Na-rich partial melts from newly underplated basaltic crust: the Cordillera Blanca Batholith, Peru. J. Petrol. 37, 1491-1521.

Rapp, R.P., 1997. Heterogeneous source regions for Archaean granitoids: experimental and geochemical evidence. In: De Wit, M.J., Ashwal, L.D. (Eds.), Greenstone Belts. Clarendon Press, Oxford, pp. 267-279.

Rapp, R.P., Watson, E.B., 1995. Dehydration melting of metabasalt at 8-32 kbar: implications for continental growth and crust-mantle recycling. J. Petrol. 36, 891-931.

Richard, P., Shimizu, N., Allègre, C.J., $1976 .{ }^{143} \mathrm{Nd} /{ }^{144} \mathrm{Nd}$, a natural tracer: an application to oceanic basalts. Earth Planet. Sci. Lett. 31, 269-278.

Rollinson, H.R., 1993. Using Geochemical Data: Evaluation, Presentation, Interpretation. JohnWiley, NewYork.

Santos, T.J.S., Fetter, A.H.W., Van Schmus, R., Hackspacher, P.C., 2009. Evidence for 2.35 to $2.30 \mathrm{Ga}$ juvenile crustal growth in the northwest Borborema Province. NE Brazil. Geol. Soc. Spec. Publ. 323, 271-281.

Silva, L.C., Armstrong, R.W., Noce, C.M., Carneiro, M.A., Pimentel, M.M., PedrosaSoares, A.C., Leite, C.A., Vieira, V.S., Silva, M.A., Paes, J.C., Cardoso Filho, J.M., 2002 Reavaliação da evolução geológica em terrenos Pré-cambrianos brasileiros com base em novos dados U-Pb SHRIMP, Parte II: Orógeno Araçuaí, Cinturão Mineiro e Cráton São Francisco Meridional. Rev. Bras. Geociênc. 32, 101-137.

Smithies, R.H., 2000. The Archaean tonalite-trondhjemite-granodiorite (TTG) series is not an analogue of Cenozoic adakite. Earth Planet. Sci. Lett. 182, 115-125.

Smithies, R.H., Champion, D.C., Cassidy, K.F., 2003. Formation of Earth's early Archaean continental crust. Precamb. Res. 127, 89-101.

Stevenson, R.K., Henry, P., Garieǐpy, C., 2009. Isotopic and geochemical evidence for differentiation and crustal contamination from granitoids of the Berens rive subprovince, Superior province, Canada. Precamb. Res. 168, 123-133.

Sun, S.-S., McDonough, W.F., 1989. Chemical and isotopic systematics of oceanic basalts: implications for mantle compositions and processes. In: Saunders, A.D. Norry, M.J. (Eds.), Magmatism in the Ocean Basins, 42. Geol. Soc. Spec. Publ., pp. 313-345.

Tanaka, T., Togashi, S., Kamioka, H. Amakawa, H., Kagami, H., Hamamoto, T, Yuhara, M., Orihashi, Y., Yoneda, S., Shimizu, H., Kunimaru, T., Takahashi, K., Yanagi, T. Nakano, T., Fujimaki, H., Shinjo, R., Asahara, Y., Tanimizu, M., Dragusanu, C., 2000. JNdi-1: a neodymium isotopic reference in consistency with LaJolla neodymium. Chem. Geol. 168, 279-281.

Taylor, S.R., McLennan, S.M., 1985. The Continental Crust: its Composition and Evolution. Blackwell, Oxford.

Teixeira, W., Carneiro, M.A., Noce, C.M., Machado, N., Sato, K., Taylor, N.P., 1996. Pb, Sr, and Nd isotopic constrains on the Archaean evolution of gneissic-granitoid complexes in the southern São Francisco Craton, Brazil. Precamb. Res. 78, 151-164.

Teixeira, W., Sabaté, P., Barbosa, J., Noce, C.M., Carneiro, M.A., 2000. Archean and Paleoproterozoic evolution of the São Francisco Craton, Brazil. In: Cordani, U.G., Milani, E.J., Thomaz Filho, A., Campos, D.A. (Eds.), Tectonic Evolution of South America. 31st Int. Geol. Cong, pp. 101-137.

Toledo, C.L.B., 2002. Evolução geológica das rochas máficas e ultramáficas no Greenstone Belt Barbacena, na região de Nazareno, MG. Unpublished $\mathrm{PhD}$ Thesis. Instituto de Geociências, Universidade de Campinas, Campinas, Brazil, 307 p. 
Vasquez, M.L., Macambira, M.J.B., Armstrong, R.A., 2008. Zircon geochronology of granitoids from the western Bacajá domain, southeastern Amazonian craton, Brazil: Neoarchean to Orosirian evolution. Precamb. Res. 161, 279-302.

Whalen, J.B., Percival, J.A., McNicoll, V.J., Longstaffe, F.J., 2002. A mainly crustal origin for tonalitic plutonic rocks in the Western Superior Province, Canada: implications for late Archean tectonomagmatic processes. J. Petrol. 43, 1551-1570.

White, R.V., Tarney, J., Kerr, A.C., Saunders, A.D., Kempton, P.D., Pringle, M.S., Klaver, G.T., 1999. Modification of an oceanic plateau, Aruba, Dutch Caribbean: Implications for the generation of continental crust. Lithos 46, 46-68.
Willie, P.J., Wolf, M.B., van der Laan, S.R., 1997. Conditions for formation of tonalites and trondhjemites. In: De Wit, M.J., Ashwal, L.D. (Eds.), Greenstone Belts. Clarendon Press, Oxford, pp. 256-266.

Yuan, C., Sun, M., Xiao, W., Wilde, S., Li, X., Liu, X., Long, X., Xia, X., Ye, K., Li, J., 2009. Garnet-bearing tonalitic porphyry from East Kunlun. Northeast Tibetan Plateau: implications for adakite and magmas from the MASH Zone. Int. J. Earth Sci. 98 1489-1510. 